\title{
AZ EZREDVÉGI EURÓPAI UNIÓ TERÜLETPOLITIKAI CÉLKOMPOZÍCIÓI
}

\author{
KŐSZEGHY ATTILA
}

\begin{abstract}
„A politika annyit tesz, mint kemény deszkákat fúrni át, erőteljesen és lassan, szenvedéllyel, ugyanakkor arányérzékkel. Való igaz, és minden történelmi tapasztalat azt igazolja, hogy az ember nem érné el a lehetségest, ha nem törekedne a lehetetlenre."
\end{abstract}

(M. Weber, 1995)

(A regionális politikák arculatváltása az ezredfordulón) Az európai integráció folyamata látszólag ártatlan kutatási témák sokaságát kínálja a gazdaság- és társadalomkutatók részére. Valójában borotvaélen táncol, aki az adatok tömegéből olyan összefüggéseket, folyamatképet próbál feltérképezni, amelyek alapján nem tünik elkerülhetetlennek a regionális gazdasági különbségek további növekedése, a munkahelyek számának folyamatos csökkenése, ${ }^{1}$ vagy pl. arra tesz kísérletet, hogy kulturális sokszínűségként adja elő a rezervátumokba szoruló helyi kultúrák és a kizárólagosságra törő globális médiasémák együttesét.

A hazai kutatók regionális folyamatokkal foglalkozó munkái a területi folyamatok és az azokat alakító támogatási szertartások bemutatása mellett igen óvatosan utalnak a korlátozhatatlanná vált világkereskedelem és a globális tőkemozgások negatív következményeire (Horváth, 1998b; Segesváry, 1998; Erdősi, 1998; Kopátsy, 2000). Feltevésem szerint az áramlási terekként, a közvetítések - a fő sodorban a kereskedelmi, pénzügyi és információ-mozgások - színtereként felfogott te-

* Kőszeghy Attila Területpolitikák racionalitása az Európai Unió területpolitikai célkompoziciói tükrében c. doktori értekezését 1999. év végén nyújtotta be a BME Urbanisztika tanszékére. Dr. Fleischer Tamás, a közgazdaságtudományok kandidátusa és dr. Nováki Erzsébet Dsc. egyetemi tanár opponensi véleményükben a dolgozat elfogadását és nyilvános vitára bocsátását javasolták. A nyilvános vitára és az értekezés megvédésére 2000. november 27-én került sor. Az értekezés ismertetését élénk vita követte, ami után a Bíráló Bizottság az értekezés elfogadása mellett szavazott. Jelen szöveg nem az eredeti rövidítése, hanem a szerző sajátkezú, kifejezetten a lap számára készült változata. (Meggyesi Tamás, a Szerkesztő Bizottság tagja, a Bíráló Bizottság elnöke)

Kőszeghy Attila, 4029 Debrecen, Lorántffy u. 25. Tel.: (20) 972 2295, Tel./Fax: (52) 419123.

${ }^{1}$ Az Európai Unió statisztikai irodájának 1998-as felmérése szerint az Unióban a szegények aránya 20\% feletti, és tendenciájában növekvő. A legszegényebb 10\%-ra az összjövedelem 3\%-a jut (Eurostat, 1998). 
rületi struktúrák áramlás-harmonizáló átalakítására a tiltó, eröszakkal fellépő politikai erőnél hatékonyabban vezethet a politikai célok megtervezett, az egyoldalú nyereség-központúságot korlátozó összjátéka.

Az Európai Unió területfejlesztési dokumentumaiban megjelenő alapvető területpolitikai célok együttesében megkísérlem bemutatni azokat a következtetés-logikai szerkezeteket, amelyek a politikai célokhoz kapcsolódó aktivitások kölcsönhatásain át érvényesülve a társadalmi formációk múködésének harmonizálásához hozzájárulhatnak.

(Politika, területi politika ${ }^{2}$ ) A politika - kevéssé vitatott megközelítéssel - „törekvés a hatalomból való részesedésre, vagy a hatalomelosztás befolyásolására akár államok között, akár olyan embercsoportok között, melyeket egy állam foglal magában" (Weber, 1992); konfliktuskezelő és együttmüködés-formáló aktivitás a hatalmi erőviszonyok érvényesítésére (Gombár, 1994:4). Az ezredvégi közpolitikák a társadalmakban átfogóan és diffúz módon jelentkező érdekeket artikulálják. A jelenkori politikai döntések a megvalósítás során formálódnak. A megvalósítás nem mechanikus következménye a döntéshozatalnak. Az indító politikai döntés annak célmeghatározása - nem tekinthető a megvalósítási folyamat meghatározójának. Nem zárható ki, hogy a döntések céljai és a programok megvalósítás utáni értékelésének eredményei egyáltalán nem hasonlítanak egymásra (Jenei, 1997:5; Downs, 1990:993-1011). ${ }^{3}$

A regionális politikák a politikai rendszer egészében a politikai szerepek, struktúrák (törvényhozó és végrehajtó szervek), a szerepek hordozói (törvényhozók, tisztségviselők), illetve a politikai irányvonalak érvényesítése (a normák, jogi ke-

\footnotetext{
${ }^{2}$ A területpolitika kifejezésben a politika szó hatalombirtoklási mód (döntéshozó és legitimáló képesség) jelentés-oldala, és az ügyek intézésére irányuló jelentés is megjelenik. A politika szónak a gazdasági aktivitások keretében történő, az eljárási renddel majdnem szinonim értelmü használata (eszközellátási, alkatrészellátási politika) folytán a területi folyamatokra ható beavatkozások, a gyakorlati területfejlesztési eljárások is - a területpolitikák körébe tévedtek. Így fordulhat elő, hogy jóllehet a területfejlesztési aktivitás keretében megjelenő területi tervezés deklaráltan a területpolitikák eszköze (ESDP, 1997; EUREK, 1999), mégis gyakori az az értelmezés, ahol e tervezés magába foglalja a területi politikát.

${ }^{3}$ Downs a választók politikához való viszonyulásának racionalitását világítja meg, de fontos adalékkal szolgál az irreális politikai célok, programok múködésének megértéséhez is. „Ha az információ költséges, semelyik döntéshozó sem engedheti meg magának, hogy a döntés meghozatala előtt minden - azzal összefüggésbe hozható - információt megszerezzen. A létező adatok hatalmas kínálatából ki kell választania néhányat, s döntését ezekre kell alapoznia ... Azoknak a bizonyítékoknak a többsége, amelyeket gyakran hoznak fel igazolásként arra, hogy a demokrácia politikai életét irracionális (nem logikus) erők uralják, valójában inkább azt bizonyítják, hogy a hiányos információ világában az állampolgárok racionálisan (hatékonyan) válaszolnak az élet kihívásaira."
} 
retek, koncepciók kidolgozása) körén túl a döntések és alkalmazások sajátos területén nyilvánulnak meg (Almond-Verba, 1969:65-72).

A regionális politika a területfejlesztést befolyásoló érdekérvényesítés módja. A területpolitika így értelmezve területfejlesztési politika, a területfejlesztés alakulására ható politika. Területfejlesztés létezhet a rávonatkozó politika nélkül is (Kőszeghy, 1994). A területfejlesztési politika hat tényezőjét emeli ki Illés (1992: 57-58): az ország egészének regionális struktúrája kialakítását, a történelmi, politikai, etnikai tényezők figyelembevételét, az állami gazdaságpolitika filozófiáját és alapcéljait, a gazdasági rendszert, a közigazgatás rendszerét (hangsúlyozva a föderatív kormányzás erős területi aspektusát), a kormányzás funkcionális tagoltságát, a helyi önkormányzatok mozgásterét, végül a nemzetközi együttmúködésbeli viszonyokat.

A területpolitikák központi témaköre: támogatásokkal elviselhetővé tenni a hátrányos helyzetű térségek népességének kedvezőtlen életminőség-kilátásait, jövőperspektíváit, a megélhetési gondokból eredő társadalmi feszültségek enyhítése, a vonzóbb térségekbe irányuló migráció fékezése érdekében. Legalább ennyire lényeges - nem deklaráltan -, hogy az előnyös helyzetü térségek további előnyökre tegyenek szert, részben a támogatási lehetőségek alkalmas értelmezésével élve (Hörcher, 1999).

(Az európai regionális politikák a kezdetektöl az ezredforulóig) Az állami regionális politika az 1940-es években, az Egyesült Királyságban jelent meg először, regionális fejlesztési törvények elfogadásával, fejlesztési övezetek kijelölésével, az északi területek lakossága elvándorlásának megállítására. Olaszországban a déli régiók támogatására 1950-től indult fejlesztési program. Franciaországban 1955től Párizst tehermentesítő decentralizációs program indult. A pénzügyi ösztönzőkkel és szabályozókkal folyó fejlesztések ipari modernizációs programokkal nemzeti regionális politikai célokra irányultak. A hetvenes évektől formálódott ki az új, szerkezetátalakítás-orientált regionális politikai paradigma. Kulcstémái: csúcstechnológiai ipar, innovatív tevékenységek, $\mathrm{K}+\mathrm{F}$, tudomány-termelés, szolgáltatási szektor előretörése, informatika, marketing, regionális és lokális pénzpiacok szervezése, vállalkozásélénkítő alapok, kis- és középvállalkozások támogatása.

A tradicionális regionális politika növekedési pólusok stabil hálózatát feltételezte, terveken alapult, nagyvállalatokra koncentrált, a mennyiségi növekedést szorgalmazta. Az új regionális politika térben változó problematikus térségeket gondoz, programközpontú, kis- és középüzemekre orientált, a belső erőforrások mozgósítására, innovációra késztet (Horváth, 1998a:32). Az utóbbi években posztmodernként is aposztrofált regionális politika a nem gazdasági tényezők fokozódó szerepével, az innovációs miliő jelentőségével számol, beleértve a lokális 
gazdasági együttmüködéseket, helyi szokásokat, az érdekérvényesítési szokásokat (CEC 1995, 1997; Rechnitzer, 1999:40; Brunn, 1993:744-747).

Az 1991-ben Hágában megfogalmazott Európa 2000 „, A közösség jövöbeli területrendezésének perspektívái" c. dokumentum megjelenésétől az Európai Területfejlesztési Koncepció (EUREK, 1999) kimunkálásáig az Európai Unió területpolitikája - a nyolcvanas évek történéseihez képest - kevéssé változott. Az árnyalatnyi változások azonban jelentős szemléletváltás forrásai. Az a stabilitás, amely e hosszabb időtávon megmutatkozik az egymást erösitönek nem itélhetö területpolitikai célok kompozíciói terén, a figyelem előterébe emeli a területi folyamatokat alakító politikák és tervezés múködésének rejtettebb vonásait.

A kilencvenes évek Európájában az államok területi politikái országonként lényegesen eltérő arculattal jelentek meg. Platz és Samland (1993) számos európai ország kormányzati politikai dokumentumait áttekintve úgy találta, hogy három alapvető cél jelent meg, a kiegyenlités, a fejlődés és a rendezés. Előtérben álltak a gazdaságpolitikai célok, ökológiai kritériumok kíséretében. Az infrastrukturális célok elsősorban a perifériák elszigeteltségének enyhítését ígérő hálózat-fejlesztéshez kapcsolódtak. Az Európa 2000 területpolitikai dokumentum közösségi beavatkozást javasolt a határrégiókban, a régiók és városok közötti kooperáció terén, a transzeurópai hálózatok vonatkozásában (a centrum és perifériák között), a belvárosi problémakörök tekintetében (szociális integráció és környezetvédelem). Az Európai Unió regionális politikájának céljai az 1992-es Maastricht-i Szerződés szerint (I. fejezet B bekezdés): a régiók fejlettségi különbségének csökkentése, a transzeurópai hálózatok fejlesztése (közlekedés, energia, telekommunikáció), a környezeti minöség megörzése és javitása, a természeti eröforrások racionális és körültekintö felhasználása, a nemzeti és regionális sokszínüség megóvása, a minöségi oktatás-képzés fejlesztése. A szolid változások ezredvégi évtizede után a regionális politikák újabb radikális arculatváltása várható a folyamatosan növekvő jövedelmi egyenlőtlenségek elleni fellépés új ígérvényeivel.

A regionális politikák az európai egységesülési folyamatban múködő politikai aktivitások körében sajátosan színjátszó arculattal jelennek meg. A gazdaságpolitikák nézőszögéből a leghatékonyabb fejlesztési területekről történő forrás-eltérítésekként jelenhetnek meg, müködésük a globális gazdasági versenyben kedvező pozíciók elvesztésére vezethet. Szociálpolitikai nézőszögből a regionális politikák hangsúlyozott célja a jövedelemkülönbségek növekedésének megakadályozása, a munkanélküliség mérséklése, és mintegy másodsorban a fejlettség tekintetében leszakadó régiók felzárkóztatása (Gyulavári, 2000:149). De az infrastruktúrafejlesztő, környezetvédelmi, szolgáltató szektort fejlesztő kohéziós célok is úgy jelennek meg, mint amelyek a hátrányos helyzetủ rétegek társadalomból kiszorulását kívánják megelőzni. A települések autonómiájának, viszonylag jól lehatárolt, nem virtuális létének kiemelt jelentőséget tulajdonító településfejlesztő-rendező megközelí- 
téssel a regionális politikák kétes legitimitással rendelkeznek, és idegen fejlődési formák, ritmusok kikényszerítőinek tünhetnek. A társadalmi formációk müködésképére utal valamennyi megközelités, de e képben - sajátos elfogultsággal-másmás súllyal jelennek meg az egyes funkció-oldalak. A társadalmi formációk müködésének lényeges szegmenseit kell lefedniük az intézményes tagolásoknak. Ellenkező esetben a kormányzatok képtelenek lennének költségvetéseket készíteni, vagy betarthatatlan politikai ígéreteket tenni ...

(Funkcionális újramodellezés) A legáltalánosabb politikai célok, mint amilyenek az európai regionális politikák alapcéljai, végsőkig egyszerüsített társadalmiformáció-sémákra vonatkozóan fogalmazódnak meg. A tagoltabb funkcionális rendszerekbe átlépés formái nem nyilvánvalók. Különösen problematikussá teszi az ilyen irányú kísérleteket az, hogy a társadalmi formációk funkcionális rendszereinek bármiféle újabb kifejtési kísérletét az elkerülhetetlen spekulatív jelleg bélyegével ruházzák fel, de még a megközelítési irányt is diszkreditálták a Parsons (1971) funkcionális rendszer-modelljeit szinte megsemmisító, megalapozott kritikák. A funkcionális modellek megkonstruálásának módszerén túl azok értelemmel felruházhatósága is vitatottá vált a vizsgálódáshoz szükséges értelmezési konvenciók átmeneti, egyezményes érvényessége körüli posztmodern filozofálás nyomán.

A globalizációs folyamatok, a társas viszonyok feltűnő változásai és számos más, a társadalmi formációk működésének megértését igénylő kutatási téma kapcsán felmerülhet a funkcionális újraképletezés igénye. A regionális folyamatok elemzése kiváltképp igényelheti a társadalmi formációk rendszerszerủ arculatának funkció-központú megragadását. A fejlett tőkésállamok regionális politikája azonban az identitáserősítő regionalizáló törekvésektől eltérően elsősorban a gazdasági és különösen a kereskedelmi folyamatok dinamizálása és kiterjesztése nézőszögéből tart igényt a társadalmi formációk áttekinthető összképére. A további múködési szegmensek alapvetően e törekvések elősegítőiként és akadályozóiként kapnak figyelmet.

Az Európai Gazdasági Közösség szerveződésén túllépő Európai Unió irányítószabályozó aktivitása a társadalmi formációk szinte minden szegletére kihat, egyelőre anélkül, hogy a beavatkozások hatásának értékeléséhez a müködési sokszínúség, érzékenység tekintetében meggyőző modellekre támaszkodhatna.

Az utóbbi évtizedek szociológiai kutatásai a társadalom-rétegződések figyelemreméltó új modelljeit adják elő, és e modellek a szükségletek körétől a marketing tevékenységig gyakorlati jelentőséggel is bírnak. A társadalmi formációk végsőkig sematikus funkcionális képletei azonban alig vitatottak. A múködési formák tekintetében árnyaltabb, sokszínúbb új modellek kimunkálása a piaci szereplők 
számára vagy érdektelen, vagy nem is kívánatos, hiszen aligha hitelesítenék a nyereségorientált gazdasági-kereskedelmi aktivitások túlsúlyát.

Az Európai Gazdasági Közösség múködése időszakában a funkcionális alapképlet a gazdaság-társadalom duál volt, ez bővült ki Maastricht után egy harmadik múködés-szegmens - a környezet - beiktatásával, így egy ún. görögháromszög-képlet formálódott (EUREK, 1999). A korábban meghatározó gazdaságpolitikai és szociálpolitikai beavatkozási területek mellett deklaráltan erősödött a környezeti jellemzők tekintetbevételének igénye.

A területi folyamatok e múködési jellegek vonatkozásában kaptak figyelmet. A megfogalmazott problémák szinte evidenciák. Nyilvánvaló, hogy a térbeli egyenlőtlenségek növekedése a népesség fejlett gazdaságú térségek felé áramlására vezet, ott fölös munkaerőként leszoríthatja a munkabéreket. A gazdasági erő tekintetében gyenge térségek elnéptelenednek. Így az utóbbiakban benne rejlő gazdasági források nem tárulnak fel, a fejlett térségek gazdasági szereplői pedig a gyenge zónákban komoly piacokat nem építhetnek ki. A problémákra adott válaszok a politikai szereplők alku-helyzetétől, erőforrásaitól, a társadalmi türőképesség megítélésétől és ténylegesen jelentkező határaitól, a rendelkezésre álló elméletektől és gyakorlati eljárásoktól, az azokra vonatkozó tapasztalatoktól is függően igen változatosak lehetnek. Az európai regionális politikák e változatossága az európai egyesülési folyamat mentén két határozottan eltérő alapképleten belül jelenik meg.

Az 1984-ig érvényesülő képlet a hatékonyság és tartósság tekintetében bizonytalan kimenetelű, döntően az egyes államok szintjén koordinált foglalkoztatást elősegítő nagyberuházások - európai szinten kevéssé összehangolt - halmazaként jellemezhető. Egy 1988-ig tartó átmeneti időszak után - amely időszakban a tagállamok közötti koordináció a regionális politikák tekintetében alig múködött - a gazdasági közösség keretében egységes célkitüzések, elvek és gyakorlat érvényesítésére új stratégiai alapelvek formálódtak, amelyek elsősorban a meghatározó támogatási források hatékonyabb felhasználására irányultak.

Számos fejlesztési kísérlet tapasztalatai alapján megállapítható, hogy máig nincs olyan siker-recept, amelynek alkalmazásával a fejlett térségek felől a tőke meggyőzően tartós fejlődést generáló módon és erővel fordul a fejletlen térségek felé. A fejlett gazdaságú zónák közötti és a fő fejlődési zónáktól távoli peremeken fekvő fejletlenek saját forrásainak fokozott mozgósítása és új fejlettségi ismérvek legitimálása vált szükségessé. Kapóra jött a természeti és kulturális értékeket mint turisztikai termékeket felértékelő turizmus és a biotermékek iránti növekvő igény. A természeti és kulturális értékek ,állagmegóvása”, a bemutatásukra való képesség, a vendéglátás ,extenzív” műfajainak művelése, a munkaigényes biokertészeti tevékenység, de az extenzív állattartás is sajátos jól-fejlettséggé minősülhet, így a hátrányos helyzetű térségek a legfejlettebb zónáktól eltérő módon korszerűvé vál- 
hatnak, életképesek maradhatnak. Arra nincs válasz, hogy mi történik a turisztikai aktivitás gyengülése esetén.

A hátrányos helyzetű térségek fejlesztésének deklarált szándéka és a fejlődés valósága között igen jelentős a távolság. Akkor is, ha a fejlett térségek által megtermelt fejlesztési források egy töredéke közvetlenül a gyengék gazdaságának élénkítésére és képességeik javítására szolgál, de még inkább akkor, ha az az ideológia, hogy a gyengék felfejlesztési forrásainak előállításához először a fejlett térségek versenyképességét kell tovább erősíteni. A deklarált politikai célok és a megvalósuló változások viszonyát kiválóan érzékelteti a periférikus térségek elérhetőségének javítására irányuló, fontossági sorrendekkel, közvetett hatásokkal nem számoló közlekedési hálózatfejlesztésre irányuló területpolitikai cél, és a megvalósult, összességükben csekély nagyságrendủ fejlesztések, amelyek a deklarált elhatározásokkal szemben döntően a centrum-térségekben realizálódtak (Erdősi, 1998:50).

(A területi politikák szinterei: a társadalmi formációk) A társadalmak valamennyi múködési és szerveződési jellemzőjének együtteseiként értelmezhető társadalmi formációk a rendszerszerú emberi együttélési formák legátfogóbb keretei. E keretben sajátos szegmensként jelennek meg a területpolitikai aktivitási formák. A társadalmi formációk térbeli jellemzőinek - a területi folyamatoknak és struktúrák$n a k$ - a kiemelése földrajzi definíciók sokaságára vezethet. „A gazdaság térbeliségét a gazdaságföldrajz, a regionális gazdaságtan, a társadalomét a településszociológia, a társadalomföldrajz, ... a politikáét a politikai földrajz vizsgálja" (NemesNagy, 1994:13). A ,társadalmi formációk” más, kevésbé térbeli meghatározottságú oldalai is kiemelhetők (Hradil, 1987; Meggyesi, 1997). A ,társadalmi integráció ” a kapcsolódások rendszerét hangsúlyozza, a „nemzetgazdaság”, „ország-gazdaság" történetileg adott társadalomszerveződési keretek között a gazdálkodás szerveződésére koncentrál.

A területi folyamatok értelmezése nem vitatott abban a tekintetben, hogy ezek a folyamatok a társadalmi formációk valamennyi más nézöszög felöl tekintett vetületi képe mélyén, „hátterében” jelen vannak. A megfigyelhető politikai-gazdaságikulturális/környezeti jelenségek térbeli vonatkozásaikban megragadhatók, és e térbeli vonatkozások összessége alkotja a területi folyamatok összképét.

A területi folyamatok a települési és régió-individuumok politikai, gazdasági, kulturális müködésképéből elvont képletek. E képletek inverzei a folyamat-terek, divatos megfogalmazással az áramlási terek. Ez a megközelítés a települések, régiók közvetitő müködését hangsúlyozza. Az Európai Unió politikai arculatának alakulása azt tükrözi, hogy a települések, régiók működésképében a konvencionális 
müködési oldalak - politikai, gazdasági, kulturális oldalak - mellett a közvetitöi„áramlási” szegmens egyenrangú szereplöként jelenithetö meg.

A társadalmi formációk térbeli folyamatainak értelmezési kísérletei körében kiemelkedő jelentőségű Nijkamp és Reggiani (1992) Interakció, evolúció és káosz a térben c. munkája. Középpontjában az emberi aktivitások térbeli formáinak elemzésére kidolgozott Térbeli Interakciók Modelljei (SIMs) állnak. E modellek a térbeli áramlásokat - emberek, javak, információk - mozgásait modellezik. E modellezés eszköztárát a hagyományos lineáris programozás, a térbeli input-output modell, a hálózat - egyensúlyi modellek mellett a gravitációs elmélet, ${ }^{4}$ illetve az entrópia-elmélet képezi. A „társadalom-fizikai” megközelítés mellett az ötvenes évektől követhetően létjogosultságot nyertek a társas viselkedési formák analógjaira építő térbeli folyamat-modellek. A hetvenes évektől a térbeli interakciók kutatásának két fő iránya alakult ki. A makro-jelenségekre orientált entrópia-elmélet és a mikro-jelenségek körére a „diszkrét választások modell” alkalmazása. Az entrópia-elméleti megközelítés a geometriai és lineáris programozási modellekkel együttmüködve alkalmasnak mutatkozott a soktényezős regionális folyamatok elemzésére.

A regionális rendszerek vizsgálata körében a nyolcvanas évek közepétől kerültek előtérbe a dinamikus és sztochasztikus térbeli interakciós modellek; a sztochasztikus optimális kontroll analízis, az ökológiai alapú elméletek, a katasztrófaés bifurkációs elmélet és kiváltképp a káoszelmélet (Nijkamp-Reggiani, 1992:90). A katasztrófa- és káoszelméleti vonatkozások a hazai kutatások körében Nováky (1994, 1995) munkái kapcsán váltak ismertté.

A regionális folyamatok legismertebb értelmezési-modellezési kísérletei távoli tudományterületek folyamat- illetve szerkezeti képleteihez analógiás megközelítéssel kapcsolódnak. ${ }^{5}$ Egy az ökológiai alapú megközelítés eredetére utaló adat különösen említést kíván: Volterra 1926-ban megjelent, a fajok közötti viszonyokat rendszerező munkája volt az elindítója a predikciót (zsákmányolást), a kompetitív és a szimbiotikus (koegzisztenciát érvényesítő) viszonyt rendszer-alapként tekintő modellezésnek.

\footnotetext{
${ }^{4}$ A tömegvonzás newtoni fizikai jelenségére utaló analógia Ravenstein 1885-ös tanulmányában jelent meg először, az angliai városok közötti migráció tanulmányozása során. Az első formalizált meghatározást Stewart ismertette 1941-ben. A város- és regionális tervezésben a Lowry típusú modell tette népszerủvé a hatvanas évektől. A különféle relációk matematizált formulái a térbeli szereplők viselkedésére vonatkozó plauzibilis hipotézisek megerősítésére megfeleltek (Nijkamp-Reggiani, 1992).

${ }^{5}$ A folyamatokba történő beavatkozások hatása igen nehezen ítélhető meg olyan modellek alapján, amelyek megformálása nem a mindenkori beavatkozások hatásrendszerének modellezésén alapult. A városok koncentrikus körökkel és kör-szegmensekkel történő szerkezeti tagolásai kapcsán (Chicagói Iskola) ugyanez a probléma fogalmazódik meg: a változások folyamatában a kezdeti magyarázó modell szétfoszlik, és a kialakuló mozaikos kép alapján nem érzékelhető a különböző léptékben zajló mozgások egymásba szövődése.
} 
Az interakciók kifejezőiként szemlélt területi folyamatok összetett változásképe nem modellezhetô csupán a közvetítő hálók és a kapcsolódások változása alapján. Alapvető a kapcsolódási aszimmetriák tekintetbe vétele. A közvetitett jelenség térbeli pozícióinak változása nyomán a földrajzi értelemben vett helyzet megváltozása nélkül is kialakulhatnak új téri minőségek. Példázzák a névtelen települési terekből turisztikai termékekké fejlesztett térségek, amelyek az idegenforgalmi aktivitás által nemzetközi „áramlási terek” részévé válnak.

A térségek meghatározottsága e közvetítésekben többszintü: a konkrét közvetítési szituáció a közvetítés kultúráját is továbbítja. ${ }^{6} \mathrm{~A}$ területi folyamatok tágan értett infrastrukturális és média-hálózatok közvetitö formái castells-i értelemben vett áramlási tereket határoznak meg (Castells, 1996), amelyek a társadalmi formációk kulturális, politikai és gazdasági folyamatai sajátszerüségét térségi és lokális egymásba-szövödésükben, a területiség sajátszerüségeként jelenitik meg.

(A társadalmi formációk , görög háromszög” funkcióképének négyszögesitése) A társadalmi formációk fő múködési szegmenseinek körvonalazása az uniós dokumentumokban megjelenő - az ESDP (1997) és EUREK (1999) dokumentumokban a Lipcsei Dokumentum (1994) alapján végső formát öltő - területpolitikai célok értelmezéséhez nélkülözhetetlen. A területpolitikák sajátszerü mozgásterét érzékeltető múködési terület és környezeti múködési szegmensről a globális kereskedelem (beleértve a tőkekihelyezést), illetve a tágan értett kommunikációs rendszerek működés-mezőjeként - szinte túlsúlyos szegmenset képezve - válik le. E szegmens közvetitésként kaphat önálló pozíciót. Az uniós területpolitikai dokumentumokban megjelenített múködésképben a konvencionális múködési oldalak - politikai, gazdasági, kulturális oldalak - mellett a közvetítési-,,áramlási” szegmens fokozatosan egyenrangú szereplővé válik.

A társadalmi formációk müködésképére utaló eltérö vetületi képek együttese modellezésének - kísérleti - eredménye a vetületi képek (,,alrendszerek”) fogalom-térképe. ${ }^{7}$ Az egyes vetületi képek felől rálátás nyílik a rajtuk kívüli vetületi

\footnotetext{
${ }^{6}$ A turisztikai példánál maradva: az idegenforgalmi szokások, eljárások tudománya, a képzésben továbbadható ismeretek adott korszakban jellemző vonásai - ,a kontextus releváns jellemzőinek ismerete"(Searle, 1983: 222) is jelen vannak a közvetítésben. Továbbá az a kapcsolat is, amely a konkrét szituációk és a kultúra-közvetítés tekintetében fennáll. A konkrét szituációhoz eltérő szorossággal hozzákapcsoltak az azokat értelmezö-rögzítö kulturális meghatározottságok (Szécsi, 1998: 72-79).

${ }^{7}$ A társadalmi formációk logikailag téves alrendszerekre, részintegrációkra bontása során az alrendszer-kategóriák mellé rendelődhetnek azok egyes részeinek önálló alrendszerré kiemelésével képzett kategóriák, illetve alapvető részintegrációk válhatnak mellőzötté. (ENSZ HABITAT, 1976; Segesvári, 1998; Baráth, 1982; CEMAT, 1994).
} 
irányokra, és viszont. A területi politika a modell keretében a társadalmi formációk politika-szegmensének térbeli közvetitési formációkra rávilágitó oldala, vetületi képe (1. ábra).

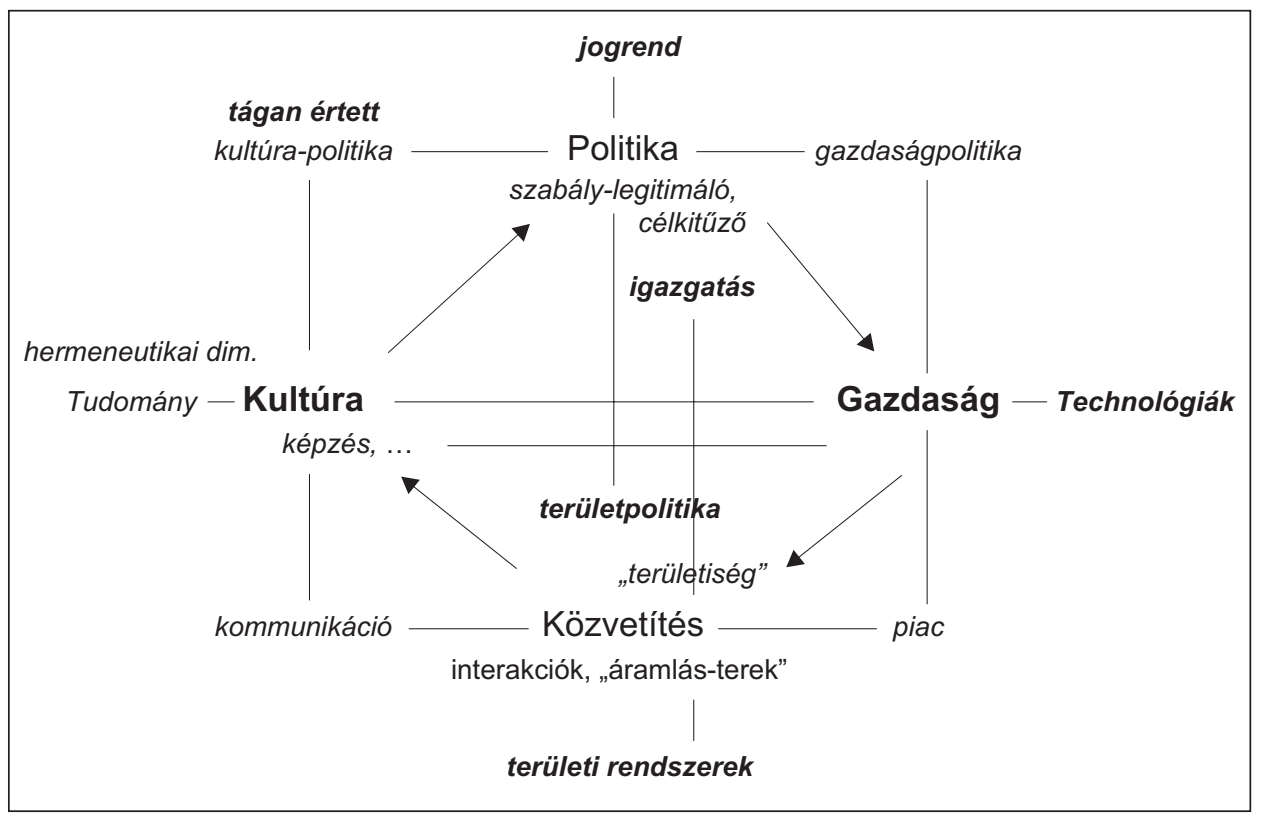

1. ábra

A politika jelen van a társadalmiformáció-modell valamennyi vetületében. Nyilvánvalóan más súllyal jelenik meg a társadalmi formáció egészét irányítóösszehangoló politika, mint pl. a gazdaságpolitika illetve a tudománypolitika, illetve közvetítés vetület-képletre vonatkozó területpolitika. A társadalmi formációk valamennyi vetületi képletének domináns jegyei valamennyi másik vetületi képben - alárendelten - jelen kell legyenek, hiszen egyazon egész egyetlen vetületi képe sem tökéletesen átlátszatlan.

A politikák és a politikák eszközeként szolgáló tervezés a maximális egyszerüség, bevéshetőség igényével a társadalmi formációk funkciósokaságát néhány összefoglaló - alrendszer- vagy vetületikép-jelölő - fogalom alá kell rendezze. A társadalmi formációk müködését jobbítani hivatott célok körében hasonló tömörítés érvényesül. A jobbitó beavatkozások e tömöritett célokra irányulnak. A harmonizáló, fejlesztő beavatkozások kedvezőtlen következményeinek számbavétele nyomán a célok és aktivitások köre módosulhat, a másként-modellezés elkerülhetetlenné válhat. 
A másként-modellezés nemcsak a jelen adottságok és jövőbeli lehetőségek másként felfogását igényli, hanem a múlt újra-rekonstruálását, egyfajta - nem historizálás értelemben vett-múlttervezést is megkövetel. Az átmodellezés kockázatának mérséklésére az értelmezések tekintetében viszonylag stabil „, bontott modell" anyagot ésszerü megtartani, hogy az új modell- és reláció értelmezések ezekhez a stabilabb modell-elemekhez orientálhatók legyenek. Az elemzés során alapul vett társadalmi formáció modell fogalomkészlete e szempont figyelembevételét tükrözi. Vállalva, hogy e funkcionális rendszerezést kétfelől is támadás érheti: a fogalmak nem eléggé fedik le a valóságosan elkülönült müködési szférákat, vagy túlzottan e szférákhoz igazodnak. Utóbbi esetben olyan jelzőkkel agyontüzdelt vagy új megnevezések alkalmazása válik szükségessé, amelyek szótárral sem követhetők.

A konvencionális modellek szinte állandó összetevői: a politika, gazdaság és a kultúra alrendszerek. A politikához kapcsoltan jelenik meg az igazgatás, esetenként önállóan is a jog, a gazdaság mellett a technika, a kultúra mellett a tudomány. A regionalizáló szemlélet erősödésével a politika és gazdaság alrendszerek mellett a területi folyamatok, ezek keretében az infrastruktúra kap alrendszer-helyet, a globális környezeti problémák erősödésével a környezet is alrendszer-szerepben jelenik meg.

A társadalmi formációkat modellező rendszerelméleti munkák kitüntetett érdeklődést mutatnak a szociális és a funkcionális integrációk fejlődéslogikája és a két eltérő integrációs szerveződés egymáshoz való viszonya iránt. A szociális integrációk mint egyének összehangolt cselekvési irányainak - pl. szocializációs eljárásoknak, kulturális hagyományoknak kommunikatív múködési folyamatban történő - fenntartói és továbbépítői jelennek meg (Habermas, é. n.:302). Nem vitatott, hogy a szociális integrációk múködését veszélyezteti a funkcionális integrációk gazdaság- és politika alrendszerének fokozódó túlsúlya. A jelenkori társadalmi patológiákat kutatóik összefüggésbe hozzák a monetarizálódás és bürokratizálódás erősödésével (Habermas, é. n.:470) a szociális integrációk körébe benyomuló technicizálódással.

A gazdaság és politika, társadalom és gazdaság: két-két fogalom, amelyek a társadalmi formációk egészét átfogó funkcióköröket hivatottak jelölni. A kétpólusú, fogalompárokra épülő, duális elrendeződések dominanciája mellett a kitüntetett fogalompárok közismertté váltak, a póluspár által jelölt jelenségkörtöl távoli jelenségek - mint mellékesek - akár név nélkül is maradhattak. A többszempontú, nem duális rendszerezések kimunkálói tehát arra kényszerülnek, hogy a duális képletek körében közismert fogalompárok mellé fogalompótló mikromagyarázatokat illesszenek. 
(Az ezredvégi Unió területpolitikai alapcélegyüttese) Az Európai Unió ezredforduló utáni regionális politikájának alakítása tekintetében részletes meghatározásokat tartalmaz az Európai Területfejlesztési Perspektíva első közreadott anyaga (ESDP, 1997), illetve annak némiképp átdolgozott szövege, az Európai Unió Területfejlesztési Koncepciója (EUREK, 1999). Elemzéseink során az e dokumentumokban szereplő meghatározásokat tekintjük a jelen politikai gyakorlat keretében fó vonalaiban elfogadottnak.

Az 1997-ben közreadott Európai Területfejlesztési Perspektíva három vezérelvet hangsúlyoz, amelyeket az ágazati, a strukturális és horizontális közösségi politikákban egyaránt érvényesíteni kell: „a termelö tevékenységek területileg kiegyensúlyozottabb elhelyezkedését, a fenntartható, folyamatos fejlödést megengedö területhasználatot, a specifikus területi szükségletek eröteljesebb és felelösebb figyelembevételét, a támogatások nagyobb koncentrációját a legfontosabb és legsürgetöbb problémák megoldására”.

Az ESDP keretében és az EUREK-dokumentumban is hivatkozott Lipcsei Dokumentumban (1994) meghatározott politikai célok:

- Egy kiegyensúlyozottabb és policentrikus városrendszer, az urbánus és rurális térségek újfajta viszonya,

- Esélyegyenlöség az infrastruktúra és a tudás hozzáférhetöségében,

- Az európai természeti és kulturális örökség körültekintö menedzselése.

- E célok eléréséhez fejlesztéspolitikai választási lehetöségeket határoztak meg, melyek igen nagyszámú további politikai változatra bonthatók le.

A politikai célok megválasztása során az alábbi általános kritériumok érvényesítendők:

- a térségfejlesztés érdekeit az ágazatiak fölé kell helyezni,

- a kiválasztott változat a legjobban szolgálja az európai érdekeket,

- a választott politikának meg kell felelnie a tagállamok érdekeinek,

- figyelembe kell venni a megvalósithatóság realitását és a potenciális hatékonyságot

„az egymás hatásait erösitő politikákat koordinálják és egymáshoz illesztik. Ezzel érhető el olyan integrált területpolitika kialakítása, amely biztositja a jobb ellátás megteremtését, a térségek fenntartható fejlödését, a fejlesztések kohézióban történö végrehajtását."

Az ESDP (1998:33) szerint „A közösségi politikák célja, hogy a fejlődés a teljes Közösséget pozitívan érintse az integráció által. Mégis, még a felzárkóztatást célzó 
politikák megvalósítása is a prosperáló térségekben fejti ki a legintenzívebb pozitív (sic!) hatást."

A területi politikák általános célokat és konkrétabb fejlesztési irányokat is megfogalmaznak. A politikai megnyilvánulások körében a célmeghatározások és az elvégzendő feladatok körvonalazása nem válik el élesen egymástól. Ahol elérendő eredményeket fogalmaz meg, ott az eredmény-realizáló fejlesztés szükséges mértéke homályban marad.

Az ESDP szövegében így jelenik meg az integrált területfejlesztés-politikai feladatterv (ESDP III. D.1. 1998:41), amelynek legfőbb elemei: kiegyensúlyozottabb területi szerkezet elérése a gazdasági és társadalmi kohézió erösitésére, a városok és régiók közötti versenyképesség kiegyensúlyozottabbá válása, az európai nagytérség minden részének jobb megközelitése, a határ menti területek és városaik megerösitése, az európai közlekedési folyosók kifejlesztése. A kohéziós elgondolások a társadalom specializálódott múködési szférái közötti konszenzus lehetőségét, harmonikus együttmúködését feltételezik.

Az EU területfejlesztéssel foglalkozó dokumentumai a területi politika formálásában résztvevőként kezelik a politikai szféra egészét. A területi politikának orientálnia kell olyan általános politikai célok felé is, amelyek csak másodlagosan kapcsolódnak a térségfejlesztési feladatokhoz, mint pl. a munkahelyteremtés a fiatalok részére vagy a fenntarthatóság problémaköre.

Az Európai Unió Maastricht utáni területpolitikai célmeghatározásai a társadalmi formációk korábban figyelemben kevéssé részesített ,szegmenseire” irányulnak. A kilencvenes évek első negyedére vonatkozóan Platz és Samland (1993) a fejlett európai országok területfejlesztési célképeit áttekintő munkája kíván figyelmet. Megállapítja, hogy a kiegyenlítés, a fejlődés és a rendezés-cél, a gazdaságpolitikai, infrastrukturális és környezetpolitikai célok valamennyi cél-együttesben megjelennek. Az előtérben a gazdaságpolitikai célok állnak. Az ökológiai kritériumok ezek kísérői. ${ }^{8}$

Az uniós területi politikák cél-meghatározásai az 1994 és 1999 közötti rövid idöszak alatt nem szembeszökö, de figyelemreméltó változást mutatnak. Az EUREK megfogalmazásában: „Az EU lépésenként gazdasági unióból környezeti unióvá és társadalmi unióvá fejlődik a regionális sokszínűség megőrzése mellett" (EUREK A. 1.3.17.).

\footnotetext{
${ }^{8}$ Vizsgálódásaik alapján a településszerkezet-fejlesztésre vonatkozóan három alaptendencia figyelhető meg:

- tisztán policentrikus tendenciájú: Németország, Ausztria, Svájc

- Dánia, Hollandia megközelítése: az országnak legyen egy nagy centruma, a többi centrumra is tekintettel. Internacionális, nemzeti, regionális funkciókat ellátó központok hierarchikus rendszerét kívánják megformálni.

- Görögország az Athént és Thessalonikit terhelő nyomást akarja enyhíteni. A kisebb központokat kívánja fejleszteni. Európai, nemzeti, regionális szintek alkotják a javasolt hierarchia-sémát.
} 
A kapcsolódó bekezdés szerint ,az EU Területfejlesztési Koncepció a kiegyensúlyozott és fenntartható fejlődésre, különösen a gazdasági és társadalmi kohézió uniós céljaira irányulnak ... A társadalmi és gazdasági követelményeket összhangba kell hozni az ökológiai és kulturális funkciókkal" (kiemelés tőlem). Itt jelenik meg az ún. görög háromszög modell (EUREK 1.3.17 bekezdés):

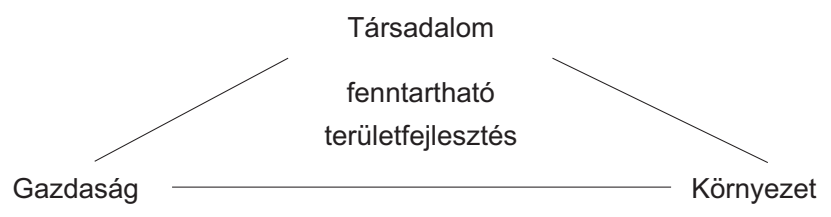

Az EUREK keretében a követendö politikai célok (az 1994-es lipcsei informális ülés célmeghatározása nyomán): gazdasági és társadalmi kohézió, a természetes életkörülmények megtartása és a kulturális örökség megörzése, az európai térség kiegyenlitettebb versenyképessége. „A térbeli kiegyensúlyozott fejlödés jegyében ezeket a célokat, illetve »vezérlö képeket « az EU minden régiójában követni kell ..." (EUREK 1.3.18.).

Az 1997-es Európai Területfejlesztési Perspektíva (ESDP) keretében megfogalmazott célok a Lipcsei Dokumentum nyomán: gazdasági és társadalmi kohézió, fenntartható fejlódés és az európai térség kiegyensúlyozott versenyképessége.

Az EUREK célháromszög képletben az ökológiai és kulturális funkció, illetve a természetes életkörülmények a kulturális örökséggel összefogva adják a társadalmi formációk „környezet vetületi” képet. E „környezet” megőrzése jelenik meg 1999-ben az EUREK területpolitikai célmeghatározásai keretében - „természetes életkörülmények és a kulturális örökség megőrzése" - az 1997-es ESDP-beli „fenntartható fejlődés” cél helyett, mint a megtartás szükségességét hangsúlyozó képlet. A fenntartható fejlődés az EUREK központi céljává emelkedett, az EUREK-célháromszög súlypontjába került.

Az általános politikai célokon túl a terület- és településszerkezet-fejlesztésre irányuló területpolitika hármas célja - lényegében a Lipcsei Dokumentumban foglaltak átvételével: kiegyensúlyozott, sokcentrumú városrendszer kifejlesztése (lásd politikai opciók: „Az EU világgazdasági integrációja több nagyobb zóna megerösitésével..."), az infrastruktúrához és a tudáshoz hozzájutás azonos mértékének biztositása, a fenntartható fejlödés, az intelligens menedzsment és a természeti és kulturális örökség védelme (EUREK 1.3.18., bővítve: 3.1.64.).

A 90-es évek elején még középponti „,kiegyenlítés” szóhasználat (pl. az 1993-as Raumordnungspolitischer Orientierungsrahmen dokumentumban: BM für Raumordnung...1993) az EUREK keretében „kiegyensúlyozásra” módosul.

Az indoklás: „Egy egyoldalúan kiegyenlitésre irányuló politika meggyengitené a gazdaságilag erösebb régiókat, egyúttal az elmaradtak függöségét erösitené" 
(EUREK 1.3.20., p. 11). Az EUREK 2000 (22, p. 73) bekezdése szerint pedig ,.. a kiegyensúlyozott településstruktúra erősítésére utakat és eljárásokat kell találni, amelyek által a városok és régiók kiegészitik egymást és kooperálnak egymással”. A szereplők erőviszonyainak, versenyképességének jelentős különbsége a „kiegészítő viszonyulás" keretében tartósan fennmaradhat.

A kohéziós programokban megnyilvánuló politikai szándékok szerint az erős gazdasági szereplőknek kedvező piacliberalizáció vesztesei - a kedvezőtlen adottságú térségek - számára a növekedési feltételek aktivizálásával fejlödési esélyt adnak (Horváth, 1998a:316). A gazdasági unió keretében a hátrányos gazdasági helyzetű térségek felzárkózása azonban nagy valószínűséggel nem valósulhat meg. Az elmúlt évtizedben a társadalmi és gazdasági kohézió elérésére fordított erőfeszítések a gazdasági önzés és a társadalmi szolidaritás küzdelmét jelentették, ahol a kedvezőtlen adottságú térségek támogatási forrásainak jelentős hányada is a fejlett térségekbe folyt át. Ennek tükrében a gazdaságcentrikus Unió környezeti és társadalmi unióvá alakításának deklarálása mentőprogramnak hat. A program nem annyira irrealitása, mint sajátos hatásmechanizmusa miatt érdemel figyelmet.

A környezeti unió felé haladva a gazdaságilag gyenge, ökológiai és kulturális adottságokkal rendelkező térségek támogatása erősödhet, de újólag a fejlett térségekbe visszavándorló forrásokkal. A gazdaság-társadalom-környezet háromszögben a gazdaság felelössége a társadalmi kiegyenlitö törekvések tekintetében elhalványul, söt, a sajátos környezeti adottságok felértékelése az egyenlötlenségeket egyenesen szükségszerüvé stilizálhatja.

$\mathrm{Az}$ uniós fejlesztő programok mérlege: „a legmagasabb és legalacsonyabb (munkanélküliség) rátájú 25 régió különbsége az 1983. évi 3,6-szorosáról 1995-re 4,9-szeresre emelkedett" (Horváth, 1998:362). Valószínű, hogy ilyen programok nélkül a helyzet még kedvezőtlenebb lenne, de az is érzékelhető, hogy a gazdasági koncentrációs folyamatok ellenében hatni kivánó kiegyenlitésnek a kialakult támogatási szisztéma mellett nincs realitása. A hátrányos helyzetü térségek szempontjából a kohéziós programok EUREK-beli átértelmezése és az e képlethez kapcsolódó „környezeti és társadalmi unió” felfogás - tetézve a túlméretezett bürokrácia terheivel (Weber, 1995:98-99) - nem mutat fel meggyőző fejlődési perspektívát.

(A fenntartható fejlödés ${ }^{9}$ érvényesülésére vonatkozó elgondolások) A nyilvánvaló környezeti károsodásokon túl a rurális térségek lakosságának helyben tartására tö-

\footnotetext{
${ }^{9}$ A Brundtland Bizottság megfogalmazása szerint „,a fenntartható fejlődés olyan fejlődés, amely kielégíti a jelen szükségleteit anélkül, hogy kétségessé tenné a jövő generációi számára majdani saját szükségleteik kielégítésének lehetőségét" Központi szerepben az élelmiszer hozzáférhetősége, egészséges ivóvíz, egészségmegőrzés, lakáshoz jutás jelent meg (ENSZ K. és FV. 1987:46). A Nemzetközi Természetvédelmi Unió és az ENSZ Környezetvédelmi Program (1992:198) szerint az
} 
rekvés, a turisztikai termékek iránti igény növekedése és a környezettudatosságra oktatás is valószínűleg jelentős szerepet játszott abban, hogy a fenntartható regionális fejlődés az ezredvégi területpolitikai célok centrumába került. Bartke (1996:1045) térségi szintekre értelmezett megfogalmazása szerint „a fenntartható fejlődés első közelítésben a földi (globális) társadalmi-gazdasági-ökológiai rendszerre értelmezett fogalom, amely a tartós és önmaga által szabályozott fejlődés kereteit jelöli ki, elhárítva a földi létet meghatározó egyensúlyi viszonyok felbomlását.” E felfogás centrumában ,a természeti folyamatokba való elviselhető beavatkozás gondolata áll, az adott térség adottságaival összefüggésben”.

A szükséges környezetvédelmi teendők köre még a kilencvenes évek elején is országonként erősen eltérő. Többnyire a partok, folyók és hegyek védelmére korlátozódtak a térségi védelmi törekvések. A nagytérségi környezeti potenciál biztosítása, a környezetterhelés csökkentése, a szennyezések térségeinek behatárolása és más eltérő részfeladat-mezők fogalmazódtak meg.

A Rurális Térségek Európai Chartája (CEMAT, 1998) szerint a rurális térségek fenntartható és integrált fejlődésének előmozdítói: a gazdasági tevékenységek és a kombinált álláslehetőségek változatosságának elősegítése, a gazdálkodó családok bevételeit és a lakosság élelmiszerszükségletét biztosító életképes mezőgazdasági szektor fenntartása, újrafelhasználható nyersanyagokból készült termékek támogatása, a turizmust és kikapcsolódást szolgáló feltételek megteremtésének és fejlesztésének támogatása, a mezőgazdasági, ipari és kereskedelmi vagy szolgáltató kis- és középvállalkozások támogatása.

Az ESDP szerint „, a nagyvárosok fenntartható fejlődése modelljén még dolgozni kell, de már biztos a következő öt elem: a nagyvárosi terjeszkedés szabályozása, a funkciók és társadalmi csoportok keveredése, a városi ökoszisztéma gondos menedzselése, a megközelítés hatékony és környezetbarát eszközeinek alkalmazása, a kulturális örökség megörzése és fejlesztése" (ESDP III.A.3.).

A fenntartható fejlődés jellemzőinek, garanciáinak számtalan megfogalmazása megszerkeszthetö. A megfogalmazott követelmények a globális környezeti problémák tükrében - még ha csupán a társadalmi formációk múködésének egy szegmensére vonatkoznak is - nyilvánvalóan elégtelenek.

(Versengés és kooperáció. Az európai térség kiegyensúlyozott versenyképessége) A versengés - az etológiai előzményeken túl - a játékelméleti modellek meghonosodásával vált a folyamat-leírások egyik meghatározó jellemzőjévé, háttérbe szo-

életet fenntartó rendszerek védelméhez, a biodiverzitás megőrzéséhez a szennyeződések megelőzésére, a földi ökoszisztémák integritásának helyreállítására és fenntartására, valamint a védett területek átfogó rendszerének kifejlesztésére egyaránt szükség van. 
rítva azokat a konfliktuselméleti megközelítéseket, amelyek a társadalmi formációkat alakító folyamatokban az antagonisztikus ellentétben álló erők harcát hangsúlyozták. A szembenálláshoz, csapásméréshez, mások vereségének eléréséhez képest a versengés mint az azonos irányban haladva megelözésre törekvés kevésbé kíméletlen aktivitásként jelenik meg. A lemaradás, a hátraszorulás még nem minősül vereségnek, a veszteségek helyrehozhatók.

A városok és régiók versengése a jelen és jövő területi folyamatai meghatározó jellemzőjeként jelenik meg az Európai Unió területpolitikai dokumentumaiban. A térségek és települések versenye a gazdaság, politika, kultúra sajátos múködési szegmensei vonatkozásában jelenik meg, pl. a képzett munkaerő megszerzése, az infrastruktúra fejlesztése terén, az oktatásban, a kutatásban, az információk hasznosításában.

Nyilvánvaló, hogy a kíméletlen verseny „,végső fokon a versengő felek kimerüléséhez, bukásához, és egy »nevető harmadik « fél győzelméhez vezethet" (Korompai, 1996:57). Bár ebből oksági megközelítéssel nem következik, a versengést mértékre fogó aktivitásként számos politikai megnyilatkozás a hálózatokban formálódó kooperációt jelöli meg (Commission of the EC, 1991:59-60): „E hálózatok az egyes települések vagy a régiók közötti együttmüködés révén küszöbölik ki a piaci verseny hátrányait. Ez a folyamat ugyanakkor a flexibilitás és a specializáció előnyeit is elérhetővé teszi" (Korompai, 1996:58). A fizikailag nem érintkező városok együttmüködésének, a horizontális kapcsolatok erősítésének szorgalmazása azon az elképzelésen alapul, hogy a települések funkcionális összefonódása révén nagyszabású urbanizált tájak alakulhatnak ki, amelyek együttesükben az USA és Japán „település-folyosóival” versenyképessé válhatnak.

A nem-versengésre kiépült szerveződések, aktivitások megbomlásának, az évszázadokon át kialakult határok felszámolásának következményeivel a dokumentumok nem foglalkoznak. A térségek, települések verseny-világából „kihullottak” és a kooperációs hálózatokból kimaradók a jelen regionális politikák tükrében megtürésre ítéltek, akár a foglalkoztatás világában a képzési verseny vesztesei. A kooperáció ilyen értelemben nem képes korrigálni a versengés okozta zavarokat. A nem versengők mindennemü kooperálása pedig a versengő tevékenységek stabilizálója lehet. Különösen akkor, ha sikerül a kooperációs szerveződéseket támogatási forrásokért pályázó kísérletekre aktivizálni, így pszeudo-versengővé tenni.

Az uniós dokumentumok - pl. az ESDP II.B.2. fejezete - megállapítják, hogy a gazdasági liberalizáció ,,az európai térség további dualizálódására és bizonyos területek marginalizációjára vezethet, melyek nincsenek kellően felkészülve az élesebb versenyre”. „Összességében valószínüsíthető, hogy (a gazdasági tendenciák) a területi gazdasági különbségek irányába fognak hatni.” „A térségek csak úgy válhatnak versenyképessé, ha kis- és nagyvárosaik a gazdasági fejlődés motorjaivá válnak. A verseny előidézheti a sikeres és kevésbé sikeres városok polarizációját." 
Utalás sincs arra, hogy a kíméletlen város-versengés vesztesei mentőövet kaphatnak. A térségek, városok tartósan nem imitálhatnak nyereségmaximálásra törő vállalkozásokat. Nincs mérték arra, hogy mely városnak milyen mértékben illő nyernie, és a „kevésbé nyertesek” hanyatlásának milyen mélységei viselhetők el.

Az eltérő karakterü térségek, városok versenyképessé válását elősegítő eszközök - a starthelyzetbeli, illetve külső feltételek tekintetében fennálló különbségeket is tekintetbe véve - elviselhetetlenül költségesek lehetnek. A komplementaritásra épített város- és térség-viszonylatok kisebb költségekkel kialakíthatónak tünnek.

Jellemző játékelméleti megállapítás, hogy a stabil együttmüködő szereplőkkel rendelkező gyengék kívánnak inkább kooperálni, a nyerésre esélyes, erős befolyással bíró szereplők előnyben részesítik a versengést, az elszigetelt gyengék pedig rákényszerülnek a versenyre, egy konszenzusalakítás során várható aránytalan veszteségek elkerülésére (Allan-Schmidt, 1994:215). A kooperációk körében azok gyakori felbomlása is teremt veszteseket, amennyire a nyugati fejlett államok szövetkezési tapasztalatai alapján megállapítható (Brunda, 1994). A térségek, települések versengése az előfeltételek és környezeti viszonyok különbsége folytán egyenlőtlen. A komplementaritás, amely a szereplőknek egy kevéssé domináns körében érvényesülhet, a kialakult hierarchia-viszonyokat stabilizálja.

Az európai térség versenyképességének kiegyensúlyozására irányuló célkitüzés olyan politikai erőt feltételez, amely a nyertes térségek számlájára törekszik a vesztes térségeket esélyes versengőkké formálni. „A magasan fejlett térségek más tagállamok térségei rovására is fejlődnek, ez a hatás nemzeti szinten nem egyenlíthető ki, az európai politikáknak kell időben tekintettel lenni erre a problémára" (EUREK 1.1. 2.).

A fejlettségbeli egyenlőtlenség mértékének megítélésére az összehasonlításokban szereplő térségek, települések életképessége eltérő jellemzőinek súlyozása szükséges. Az Európai Bizottság által elfogadott kísérleti program hét összehasonlíthatóságot megalapozó kritériumot határoz meg, ezek között a lakosság, illetve a települési-térségi elit véleménye az elvárt létbiztonságról vagy a versengéshez való viszonyról nem jelenik meg (EUREK 4.2.171.). A kritériumok között a természeti és kulturális érték mint megőrzendő valóság-zárvány jelenik meg. A kultúra mint a társadalmi formáció aktivitásainak és szerveződéseinek értelmezője, mint belsö környezet - nem szerepel az összehasonlító vizsgálódások alapjául szolgáló kritériumok körében.

(A területpolitikai és tervezési célok „túlírása”) A területpolitikai célok irányának, a megcélzott változások irrealitása, illetve irreális kombinációs lehetőségeik megfogalmazása olyan feltételezésekre ad alapot, hogy a várható akadályok figye- 
lembevétele indokolja a célok „túlírását”. A lehetséges történések feltérképezését a konvencionális társadalmi formáció képleteknél részletesebb társadalmi formáció modell felvétele elősegítheti.

Amennyiben a társadalmi problémák enyhítésére hozott döntések nyomán (akár tervek alapján, akár azok nélkül születtek) a megvalósítás nem képes elérni egy kritikus eredményt (amely nem feltétlenül a kitüzött cél), bekövetkezhet az erők elpazarlása és a politikai presztizs elvesztése. Bardach (1977:264-265) a politikamegvalósítás forgatókönyvében olyan lépéseket javasol, amelyek számot vetnek a társadalmi entrópia problémáival, pl. a gyér irányítási és műszaki hozzáértéssel. Szükségesnek tart olyan múveleteket, amelyek rámutatnak arra, hogyan küzd meg a politika az adminisztráció olyan vonásaival, mint a színlelt cselekvés, halogatás, masszív ellenállás, az erőforrások másra fordítása. Az értékekre vonatkozó nézetkülönbségek még egyazon információk alapján is különböző cselekvésekre indíthatják a döntéshozókat, a végrehajtó bürokráciát pedig olyan intézkedésekre sarkallhatják, amelyek nem álltak a döntéshozó szándékában. A célok alulteljesítését annak tulajdonítja, hogy a megvalósítás során „,sok szereplő manőverezik egymás mellett és egymás ellen mind a végeredmény, mind a stratégiai elönyök megszerzéséért".

A célok elérését akadályozhatja a döntéshozó bizonytalan helyzetekben jellemző magatartása: késleltethet, nem ad egyértelmű választ, további információt keres, kompromisszumot köt, abból indul ki, hogy a legrosszabb változat következik be („maximin” megközelítés), döntéselméleti megközelítést alkalmaz (szubjektív módon tulajdonít valószínúségi értéket az egyes változatoknak). Fentiek indokolják, hogy a politikai célok elérésének biztonságát fokozó mechanizmusok épüljenek ki, de nem világitják meg a reálistól távol álló célok kitüzésének indítékait.

Az Európai Unió anonim politika-fogalmazói és a közös állásfoglalások személyhez nem köthetősége az egyes politikusok kockázatát csökkenti. Az ellenőrzés is elveszti súlyát, hiszen a túlzó politikai célok korrekciójára vonatkozó felhívásoknak nincs jól elérhető címzettjük. A kontroll-reakciók jelentőségét leértékeli az a lehetőség, hogy a deklarált regionális politikai célok ,finomíthatók”, módosíthatók, átértelmezhetők. Széles körben elfogadtatni szándékozott dokumentumok kollektív megfogalmazása kapcsán azonban nem feltételezhető, hogy cinizmus munkál bizonyos képtelen célok megfogalmazása során.

Nyilvánvaló, hogy a politikai és tervezési meghatározások, jövő-leírások a társadalmi formációk összetett felépítésű információ-halmazába ágyazódnak. A lehetséges jövők képe nem egyszerü oksági láncok mentén, hanem soktényezős, illetve sokszoros kapcsolódásokkal kiépült kölcsönhatások együttesében körvonalazódik. ${ }^{10}$

${ }^{10}$ A társadalmi formációk nyitott rendszere nem egyensúlyi rendszer, ahol a korrelációk intenzitása és hatása nulla, ahol a különböző lokális folyamatok között nincs kommunikáció. A politikai és 
Az Európai Unió ezredvégi területpolitikája részről részre tekintve olyan célok közelítésére irányul, amely célok egyenként és kisebb térségekben nem szembetünően irreálisak. A területpolitikai célok együttesen azonban szembetünö módon egymást kizárónak, de legalábbis korlátozónak mutatkoznak. A politikai érdekérvényesítő konfliktusok és együttmüködések bizonytalan kimenetelének tekintetbe vétele magyarázatot adhat az aktivitásokat védő-biztosító feltételek létrehozására, de egymást kizáró illetve korlátozó cél-kombinációk szükségességét és müködését nem világítja meg.

Feltételezhető, hogy a korlátozó jelleg egy területpolitikai önszabályozó rendszer lényegi része. Így gondos meghatározást kíván, hogy valóban képesek-e egymás érvényesülését mértékre fogni a területpolitikai dokumentumokban megfogalmazott törekvések. Nyomós érvek szólhatnak a területpolitikai célok ellentmondásos körvonalazásának szükségessége mellett, hiszen az ilyen jellegü célmeghatározás jelentős kockázatokkal jár. Összeférhetetlen célok kitűzése, a célok alig észrevehető mértékủ közelítése súlyos politikai tévedésnek minősülhet.

Külső körülményekre alapozottan eltérő mértékủ változások előirányozhatók a területi folyamatok különböző oldalai mentén, de ezek oksági láncokban nem értelmezhetők, nem tervezhetők. Belső konfliktusoktól kevésbé zavart, nagyobb mértékben teljesíthető cél-együttes közelítése érdekében a társadalmi formációk bizonyos müködési oldalai figyelmen kívül maradhatnak. De nem csekély a valószínúsége annak, hogy ez esetben a meglévők mellett új, a meglévőknél is kezelhetetlenebb feszültségek alakulhatnak ki. Tehát van érv bizonyos mértékig összeférhetetlen célok együttes közelítésének vállalására, és nagy jelentősége lehet azoknak a tényezőknek, amelyek a célok összehangolására, mértékre fogására alkalmasak.

Az irreális, „túlírt” területpolitikai célok szükségességének igazolására túlontúl egyszerü érvek sora is megfogalmazható:

- A realitás-közeli területpolitikai célok a területi folyamatok szereplö-sokaságától körültapogatva és fazon-igazítva felismerhetetlenné változhatnak.

- Több „kisebb”, reálisabb cél között a tájékozódás nehézkes.

- A jelentéktelen változtatásokat előirányzó politikák ellenében az azokat bátortalannak minősítő, sarkosabbak kerülhetnek elötérbe.

a tervezési aktivitások mentén jellemző a korrelációk sűrűsödése és sokasodása, az intenzívebb információcsere. Intenzív információáramlás jellemzi a területpolitikai felhatalmazások legitimitásának nyilvánvalóvá tételét; a beavatkozási szituációk megfigyelését; a beavatkozások típusos következményeinek meghatározását; érdekek érvényesítésének jogosságát igazoló gondolatok értelmezési mezővé formálását (általános társadalompolitikai és gazdaságpolitikai igazoló elvek, szokványos evidenciák [korszerüség, haladás, fejlődés, környezetvédelem], szakmai igazoló elvek, adott szakterületek jogilag intézményesített elvei). 
- A társadalmi formációk politikai szférájában a realitás-közeli területpolitikai célok nem attraktívak, más politikák kitakarhatják azokat. Másfelől a célok mozgósító hatása csekély lehet, és a célokat legitimáló reflexiók nem alakulnak ki.

A célok mértéktelen irrealitásából eredő problémák talán kevésbé kézenfekvőek, de figyelmet érdemelnek. Amikor a területpolitikák a feltételfüggőséget hangsúlyozó reális tervekből már le nem vezethető, távlatosabb célokat deklarálnak - nagytávú érvényességre igényt formáló módon -, a célokat az irrealitás irányába tolják el. A feltétel-kötöttségektől eltávolodva - belső mérték hiányában elbizonytalanodva-jelentéktelen eredményeket túlértékelhetnek, jelentös eredményeket lefokozhatnak. A politikai célok túlzásai ilyen megközelítéssel nem járnak nagyobb kockázattal, mintha azok a realitás közelében maradnának. A nagymérvü túlzások a területpolitikai és területi tervezési szereplök részéröl feleslegesen nagy átstilizáló-átértelemző erőfeszítéseket igényelnek.

A végállapot-leíró utópikus politikai célok körétől távol maradnak a politikák, amint eszköztáruk, mozgásterük csökken. ${ }^{11}$

Az ezredvégi uniós területpolitikák részben a korlátozott eszköztár, részben a deklarált stratégiai elvek (Miklóssy, 1995; Kengyel, 1996) folytán a perspektívákat (kitekintési irányokként értve), tendenciákat, opciókat részesítik előnyben. A területi politikák a társadalmi formációkat nem tekinthetik olyan mértékben stabilnak, hogy ún. jól strukturált tevékenységrendszert feltételezve a célokat mereven definiálják, e célokhoz az elérés optimális megoldását hozzárendeljék. A területi politikák rosszul strukturált problémákkal foglalkoznak. Észlelik a jelenlegi és a kívánatos helyzet közötti különbséget, de sem a jelen, sem a kívánatos állapot, sem a kívánatoshoz vezető aktivitások ,hogyanja” nem egyértelmü, számos vonatkozásban határozatlan. A problémamegközelítés ,puha” módszere alkalmazható: mind a problémamegfogalmazás, mind a megoldás fázisában a folyamatos kérdésfeltevés eszközét szükséges alkalmazni. Az egyetlen optimális megoldás helyett a tanulás a problémamegoldás alapvető megközelítési módja.

Az irreális területpolitikai célok megfogalmazása és hangsúlyozása utalhat arra, hogy e távoli célok „,ernyője” alatt megfér a problémakezelés ,puha” módja. Csakhogy a célok tendenciákká, irányokká szelidítve sem kevésbé irreálisak. Csupán a célok elérésének térbeli-időbeli távlatait hagyják meghatározatlanul. A „puha” megközelítés mellett az irányok, tendenciák lehetséges változásainak kellene hangsúlyt kapniuk. Erre kevés utalást találunk. Tehát a szelidített célkitűzések éppen korlátozhatják is a „puha” problémakezelés mozgásterét (Checkland, 1987).

\footnotetext{
${ }^{11}$ Franciaországban „1976-tól a tervezés fokozatosan formálissá vált, középtávú célkitűzései - a növekvő infláció és a fokozódó munkanélküliség miatt - rendre nem teljesültek. Az óvatos tervek később már csak irányokat szabtak meg és prioritásokat jelöltek ki” ( Barta, 1992:25).
} 
A területpolitikai célok körébe belemosódhatnak a területpolitika arculatának megtervezését, a területpolitika-alakítás módját orientáló célok. Ezen célok érvényesítői nem külső politika-tervezők. A területpolitikák formálói, akik e politikák által a területi folyamatok alakítói is, az önformáló aktivitás, önirányítás, önszabályozás műveleteivel önmaguk politikai arculatának megtervezői. Az ESDP területfejlesztés-politikai feladattervet megalapozó tényezőket fogalmaz meg a III.D.1. fejezetben. Területtervezési mozaikokat ad elő, amelyek eltérő kombinációi eltérő politika-képletet, ,politika-tervet” eredményeznek. Ez a terv-képlet nem irányul közvetlenül területi folyamatokra, hanem körülhatárolja, hogy a valós területi folyamatok felé forduló területpolitika mely probléma-szegmensekre legyen különösen érzékeny, illetve melyek tekintetében legyen elzárkózó, politikai magatartásmódot körvonalaz.

A regionális folyamatokba történő beavatkozások formái az elmúlt évtizedek során jelentős mértékben változtak. A regionális folyamatok, az azokba történő beavatkozások és az eredményesség értelmezése tekintetében számos meghatározás formálódott a tervezett beavatkozási irányok távlatossága, az eljárások hatékonysága, a stratégiák konfliktuskezelő képessége, az egyes beavatkozási jellemzők szinergikussága (egymást erősítő, összehangolt fellépése) tekintetében. A jövőbeli beavatkozási formák leírása során radikális változásokkal kell számolni a globális népesedési, gazdasági, környezetváltozási és kulturális folyamatok értelmezési keretei és a legitim beavatkozási formák köre tekintetében is. A célok, koncepciók, programok, tervek, stratégiai és operatív múveletek szinte számtalan definíciója, megítélésük sokszínűsége elkerülhetetlenné teszi körülíró megfogalmazások alkalmazását, ahol a problémák és megoldási javaslatok előadására kevéssé vitatható fogalmak szolgálnak. ${ }^{12}$

(A következtetési formák láncolata és az Európai Unió területpolitikai célrendszere) Feltételezhetö, hogy sajátos racionalitás érvényesül az EU területpolitikai célegyüttesének meghatározásában és érvényesitési módjában. A célok megvalósitásának csekély hatékonysága egy ésszerü területpolitikai aktivitás pozitív eredmé-

\footnotetext{
${ }^{12}$ Amikor pl. az ESDP jövőképében még egy újgyarmatosítási kísérlet erejéig sem veszi tudomásul Kelet-Európa létét, de a nyugat-európai belső etnikai-vallási átrendeződéssel, hatmillió hektár parlagon tartott termőföldjének sorsával, vagy a túlnépesedés folytán várható migrációs nyomással nem foglalkozik, az nyilván nem véletlen. A problémák elhallgatása a tervezet egészének értelmezési keretét meghatározatlanul hagyja. Egymással ütköző célok egyidejü legitimálása következtében pedig a változtató törekvések tárgyai vagy olyan szituációk lehetnek, amelyek energiaszegények, enerváltak, vagy elegendő agresszivitást hordoznak ahhoz, hogy egyes kitérítő szabályokon túllépjenek. Az eredmény vagy jelentéktelen, vagy a tervezet nélkül is létrejött volna. A regionális politika nyeresége, hogy nem vállal fel olyan feladatokat, amelyekkel kudarcot vallhat.
} 
nyeként értelmezhetö. A közvetve egymást korlátozó célmegvalósító törekvések körében a politikai célokra irányuló aktivitás csekély eredménnyel jár, de nem válik vitatottá a célrendszer egésze. A politikai elvárások széles körére ráhangolt politikai célok megközelítésének meghatározatlan üteme, sorrendje lehetóséget ad a célok lassú közelítésének igazolására.

A társadalmi formációk és a fejlesztési aktivitások teljességre törekvő körvonalazása folytán az EU területpolitikai célok a problémák megközelitése, értelmezése és kezelése tekintetében is sajátos teljeskörüséggel jelennek meg az ezredvégi területfejlesztési dokumentumokban. E teljeskörüségre törekvés folytán a célok formálódása eltérö következtetés-logika képletek mentén történhet. E képletek a politikusi elhatározásoktól függetlenül magukban hordanak sajátos meghatározási korlátokat, az eldönthetetlenség, a véletlenek, a valószínüségi jelleg és a bizonytalanság sajátos jegyeivel. Az eltérö politikai célok következtetéslogikai meghatározottságaik révén olyan belsö korlátokkal rendelkeznek, amelyek a részleges megvalósulásra vonatkozó, külsö okokra alapozott magyarázatokat is részben feleslegessé teszik. A politikai célok együttesének csekély közelitése sokkal kézenfekvöbbnek látszik, mint azok sikeres megvalósitása.

Még izgalmasabb az a jelenségkör, ahogyan a megvalósuló változások a megcélzott változások irányától eltérnek. E jelenségek világítanak rá leghatározottabban a következtetéslogikai formák szerepére.

A területpolitikai célok és a tudományos következtetési formák (sémák) kapcsolatának megvilágításához röviden szükséges kitérni a következtetési formák kevésbé ismert képleteire és e formák láncolatának bemutatására.

(A következtetési formákra alapozott modellezés) Egy nem duális, nem ellentétpárokra épitö modellezés szervezö alapjaként fontos szerepet kaphatnak a tudományos következtetési formák, mint legkevésbé tárgyspecifikus, ugyanakkor konzisztens logikát érvényesitő szellemi konstrukciók. A következtetési formák jellemzője, hogy kezdő-lépésük megszabja a következtetési út irányát és a kimenetel számos vonását.

A tudományos modellalkotás deduktív és induktív útja közismert. A logikával foglalkozók az általánostól a speciális felé haladó, az elméletet a konkrét esetekre alkalmazó okfejtést illetik deduktív megjelöléssel, a részletektől az általános elvek, a megfigyelések tényeitől az elmélet felé haladót az induktív megnevezéssel. Peirce (1987) az általa kimunkált újabb következtetési formát, a hipotetikus következtetést - más néven abdukciót - kapcsolatba hozta a deduktív és induktív formával. Wallace (1971:18) a negyedik következtetési forma megfogalmazásának küszöbéig ért, amikor előadta a ,tudomány kereke” megnevezéssel aposztrofált ábrát a következtetési folyamat-fázisok és kapcsolódási irányok előadásával (2. ábra): 


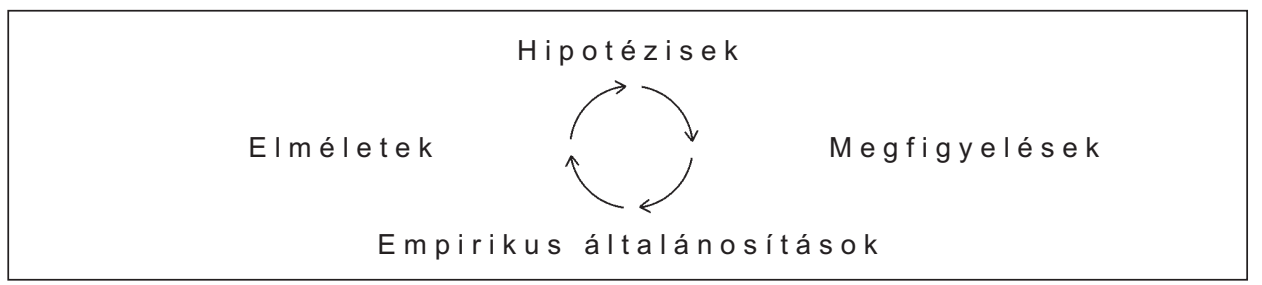

2. ábra

Más fogalomhasználattal (Kunzmann-Burghard-Wiedemann, 1991) 3. ábra:

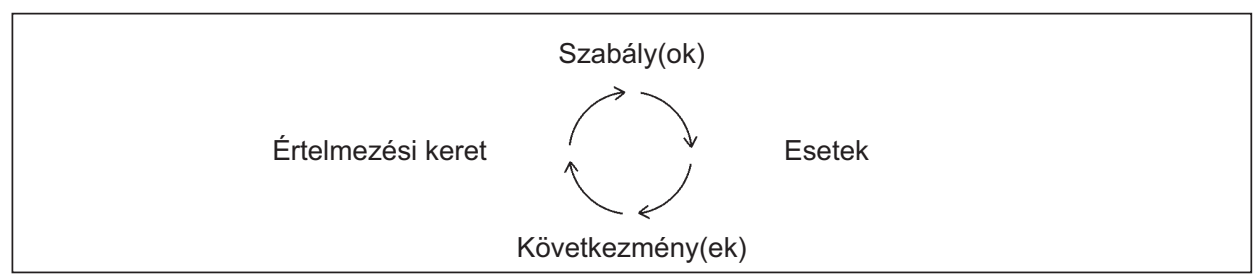

3. ábra

Jól ismert az értelmezési keretek hallgatólagos elfogadásán alapuló, a szabályok, tételek deklarálásával induló deduktív forma és a szabályok körét hallgatólagosan tudomásul vevő, az egyes esetekre e szabályokat alkalmazó induktív képlet. E sémák mellett helyet követel az eredmény/következmény felől indító abduktív és az értelmezési keretek felől építkező, autoduktív névvel illetett következtetési mód.

A Wallace-i sémában a megfigyelésekhez az induktív, az empirikus általánosításokhoz az abduktív, az értelmező-magyarázó elméletekhez az autoduktív megnevezéssel jelölt, a hipotézisekhez a deduktív következtetési út kapcsolódik. Az eltérő következtetési formák eltérö érvényességi korlátai egymásra vonatkozásaikban jelenhetnek meg.

A következtetési sémák hátterében álló matematikai képlet (4. ábra):

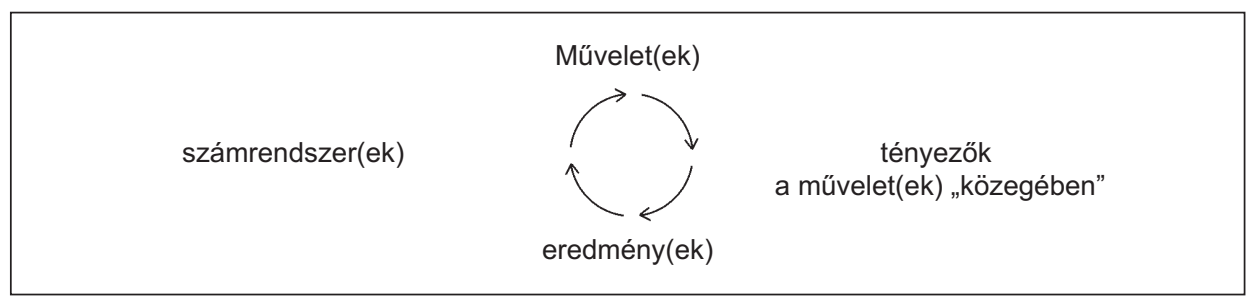

4. ábra 
Az egyes következtetési formák arculatát meghatározza a kiinduló pozíció. A négy karakteresen eltérő következtetési séma azonos összetevőkészlet alapján épül fel.

A következtetési formák négy karakteresen eltérö következtetési arculatának vázlata alapján egymásba kapcsolódásuk sajátos láncolata körvonalazható (5. ábra):

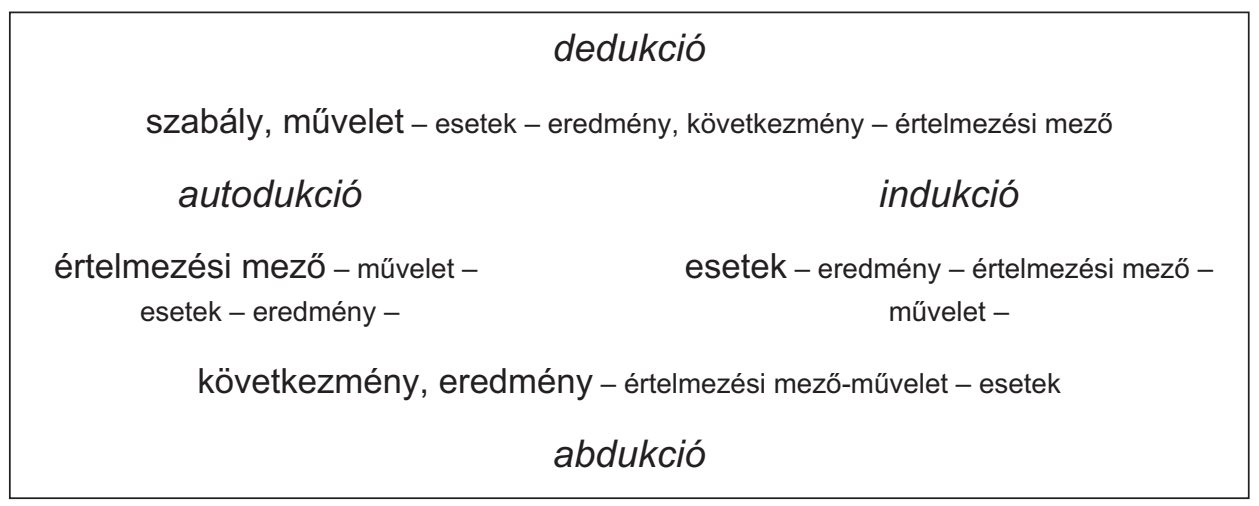

5. ábra

A következtetési formák együttesének teljeskörü, egyidejủ megragadására nem áll rendelkezésre az értelmezési formákra rátekintést kínáló vizsgálódási metaszint. A következtetési formák koherens logikai lépéssorra illeszkedése azonban a kínálkozó vetületi képeket körvonalazni és összefogni képes.

(Eltérö területpolitikai célok-eltérö következtetési formák) Az eltérő következtetési folyamatok mentén a politikai célrendszer eltérő arculat-változatai emelkednek ki, sajátos határozatlansági jellegekkel, a területi tervezés mozgásterét behatárolva. A következtetési formák, amelyek a létező folyamatok összefüggéseinek szellemi feldolgozására szolgálnak, a domináns politikai cél-arculattól függően a cél-együttes további összetevőinek a domináns célra vonatkoztatható jellemzőit emelik ki.

A következtetéslogikai út körvonalai a területpolitikai célok társadalmi formációkra vonatkoztatása során elbizonytalanodnak. A beavatkozásokra, változtatásokra irányuló politikának számolnia kell a megfigyelt folyamatokat leíró- kauzális racionalitásnak hiánytalanul megfelelö-következtetési képletek alapján várható és a valóságosan bejárható következtetési utak eltéréseivel. 
A politikai célok megfelelő megválasztásuk esetén - nem kölcsönösen, hanem közvetítéseken át - egymás előzményei, illetve következményei. E kapcsolatsor recepciója során a következtetéslogikai lépéssor mentén elkerülhetetlen meghatározási korlátok, bizonytalanságok a deklarált célok szükségszerü sajátjaként jelennek meg, az irreális célokat irányjelzőkké szelídítik, az azok irányába mutató szerény elmozdulások pedig lényegessé minősülhetnek.

Kiinduló feltevésem szerint a területpolitikai célok együttesének irrealitása nem vezethető vissza sem felületességre, sem „,kötelező” politikai túlzásokra, és nem értelmezhető a biztonságosabb célközelítés eszközeként sem. Az egyes területpolitikai célok elötérbe helyezése az azonos általánossági szinten álló további célok érvényesitési lehetöségeit szükíti - amennyiben a célok sora a következtetési formák fö szegmenseire illeszkedik. A célok kombinációkba foglalt együttesében a domináns célok mellett érvényesülő ,,másodlagos cél-arculatok” világossá teszik a beavatkozások már nem tervezhetö, elfogadhatatlan politikai kockázatot jelentö, kiszámithatatlan következményekkel járó körét, a következtetési fázisokra jellemzö karakter-jegyek eltérö jellegü határozatlanságával, elmosódásával.

Az alapvető politikai célok (EUREK 1.3.) (zárójelben az 1997-es ESDP-szövegezés) (6. ábra):

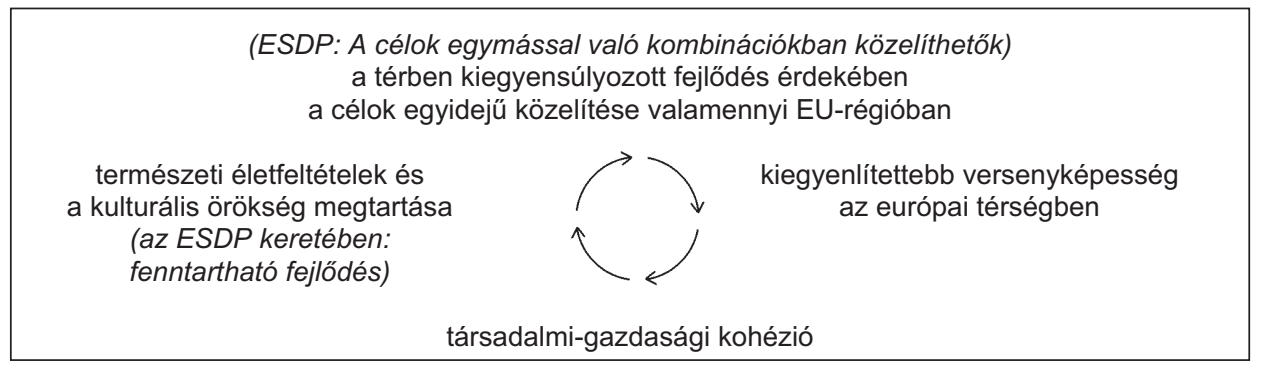

6. ábra

A területpolitikai alapcélok és a következtetési formák közötti kapcsolat modellezése koherens rendszert alkotó megközelitési formákat, eszközöket kínál. A politikai gyakorlat értelmezése, legitimációja, kísérletei és sablonjai olyan jelenségek, amelyek alakulásában a logikai vonatkozások az érdekek erejéhez képest kevéssé érvényesülnek. Az érdekek felöl rendezödö érték-prioritások elfogadtatása és érvényesitése azonban logikai utak mentén történik. A sokszereplős, stratégiaigényes területpolitika-alakítás keretében ez különösen nyilvánvaló.

A területpolitikai alapcélok - szinte értékideálokként megjelenő célok - realizálható programokig redukálódnak a következtetési folyamatok korlátozó hatása alatt. A következtetési formák tekintetbevétele árnyaltabb képet ad a területpoliti- 
kai célok megformálásának egészéröl, mint a csupán az érdekeket, a hatalmi eröviszonyokat elötérbe állitó megközelítések.

A területpolitikai alapcélok eltérő következtetési megközelítések iránt mutatnak affinitást. A versenyképesség erősitése versengő individuumok, esetek, szituációk körét, energiák kibontakoztatását, a működési intenzitás erősödését feltételezi, az egyes szituációk, esetek körére épitó induktív következtetési út alapját kínálja. Az „átrendező”, kiegyensúlyozó, harmonizáló kohéziós aktivitás abduktív következtetési úton bontakozik ki. A környezeti-kulturális értékek megtartására irányuló politikai cél - az ESDP keretében a fenntartható fejlődés cél - azt az értelmezési keretet körvonalazza, amely a további politikai alapcélok érvényesítésének mozgásterét kijelöli, autoduktív következtetési úton haladva. A politikai célok együttes közelítésére az egymást korlátozó létrehozó-kifejlesztő, hordozó-kiterjesztő és stabilizáló műveletek valamely legitimált kombinációja szolgálhat deduktív következtetési úton.

(Modellezési példák) A példák előadásmódjában az eltérő következtetési formák eltérő induló fázisait a geometriai elrendezés hangsúlyozza, a következtetési láncformák kapcsolódási egyirányúságára is utalva.

A versengéscentrikus politikai cél dominanciája esetén - a területi folyamatok versengö individuumait, ,, eseteit"elötérbe állitva - induktív következtetési logika érvényesül. Az európai térség kiegyenlítettebb versenyképességének elérésére törekedve - a versengésre kiváló térségek fontossága kap hangsúlyt.

A versengés-képletet lásd a 7. ábrán.

A kohéziós célok felöl induló következtetési lépéssor vázlatát lásd a 8. ábrán.

A kohéziós cél: a hátrányos helyzetủ térségeknek fejlődési esélyt adni, kiegyensúlyozó és harmonizáló beavatkozásokkal.

A természeti és kulturális értékek megtartása - mint sajátos viszonyitási, értelmezési alap - felöl induló következtetési lépéssor a 9. ábrán látható.

A deduktív következtetés érvényesülése legitim müveletek, szabályok alapul vételével a 10. ábrán látható.

A domináns területpolitikai célok felöl kifejtett következtetési lépések mentén a következtetési lánc megnyílik; a további területpolitikai célok „megszürt” értelmezési mezővel, érvényességi körrel, megfigyelési szituációkkal és következmény-formalizálással jelennek meg, a területpolitikai célok közötti ellentmondásokat elhalványítva. 
4

a politikai célok egyidejü közelítése keretében

a versenyképesség mellett a kohézióra érzékenyített kooperáció-képesség

$$
\nabla \text { és azok értelmezési kerete kap legitimitást }
$$

3

a környezeti és kulturális javak - mint termékek -

versengés tárgyai lehetnek, ugyanakkor a versengés értelmezői is;

a versengés határai elbizonytalanodnak

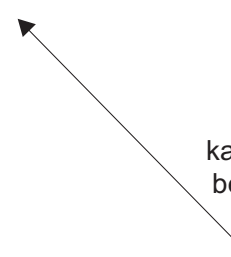

7

a kiegyenlítettebb versenyképesség sajátos megvalósulása: „álversengők” megjelenése, szereplők köre bővül

a versengés - sajátos környezeti jellemzőkhöz is kötve - szinte egyetemesen érvényesül, ugyanakkor igen lazán, szabadon értelmezhető

$$
6
$$

a kedvezményezett gyenge térségek belépése a versengők körébe a versengő karaktert eltorzítja, felhígítja; a méltányosság beavatkozások átmenetileg versenyképessé stilizálják a megtámogatottakat

a versengés mintaszerü formái, sémái, típusos jellemzői: a kohéziós eredmények - kiegyensúlyozás, harmonizáció a versengők körére vonatkoztatottak, a versenyen kívüli, rejtett előnyszerzés eszközei nem jelennek meg; az esélykülönbség-mérséklés mértéke: a hátrányok ne halmozódjanak, a gyenge szereplők kooperációkban kvázi-versengőkként léphetnek fel

\section{7. ábra}

3

az alapvető célok együttes megközelítésének eredményessége eszköz-koncentrációt igényel,
2

az értelmezési keretek a fejlettebb térségek felerősítését preferálják, a realizálási időtávot és jellemzőket igen lazán ragadják meg a környezeti értékeket a fejlettség-jellemzők körébe bevonják

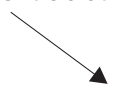

4 a szolid teljesítmények az alapvető célok túlzásainak racionalitást kölcsönöznek;

szerényebb célok érzékelhetetlen

eredményekre vezetnének
1

sikeres versengők: ltérő jellegü erősségek, a vesztesek körében a hátrányok halmozódása

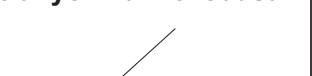


2

a legitim szabályok, műveletek köre a területpolitikai célok mindegyikére vonatkozóan lehetőségek és korlátok meghatározója, a versengésre, illetve társadalmi-gazdasági kohézióra vonatkozó célok alkalmas terepet előfeltételeznek, e terep azonban környezeti-kulturális adottságaival, ökológiai kapacitásával szintén korlátokat állít

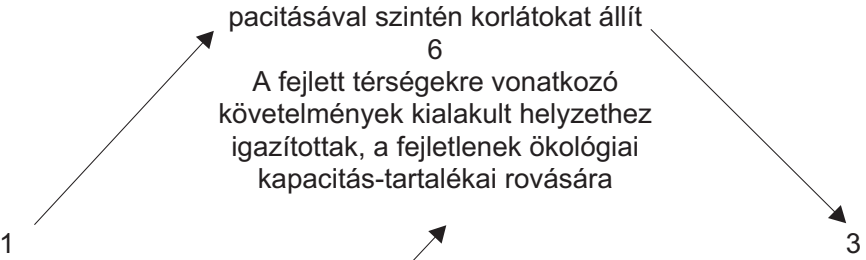

a természetes életfeltételek és

a kulturális örökség megtartása

a tisztán hatékonyságra orientált az ökológiai kapacitások tiszteletben tartása globális léptékben értelmezve 5 reálisan rezervátum-léptékủ izoláló, mumifikáló, attrakcióvá torzító programok, illetve a rurális térségek hátrányos pozícióinak átértelmezései a jellemzők

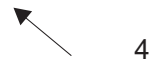

4

csekély kohéziós eredmények differenciált taglalása, versengés létjoga igazolható azzal, hogy a természeti és kulturális értékek megőrzéséhez szükséges források mielőbbi előállítását szolgálja; a jövő-forgatókönyvek e megközelítésnek elentős mértékben eltérő eredmények egybe-sablonozása

a térségek ökológiai és kulturális szempontból értelmezhetetlen sémáit adják,

a természetes életfeltételek megtartása a kohéziós programoktól idegen,

a források környezetvédelmi infrastruktura-létesítésre áttranszformálhatók

(pl. gyökérzónás szennyvíztisztítás helyett csatornázás + hagyományos tisztítók)

\section{9. ábra}

a területpolitikai célok egyidejü közelítése
érvényesítöi: területpolitikai müveletek
támogatási szabályok, eszközök

10. ábra 
A deduktív következtetési forma érvényesülése esetén - legitim múveletek, szabályok alapulvétele mellett - egy „0” jelzésű „előfázis” is megjelenik. Kiemelve, hogy a megközelítőleg formállogikai, feltétel-független következtetési út érvényességét az értelmezési keretek bizonytalansága erősíti fel.

A tér-és településstruktúra-fejlesztési célok centruma a területpolitikai alapcélok közül a térségi folyamatokba történő beavatkozás gyakorlati mozzanataihoz legközelebb álló kohéziós alapcél. Következtetési fázisokra rendezetten - az ESDP és EUREK kapcsolódó szövegrészleteivel a 11. ábrán látható.

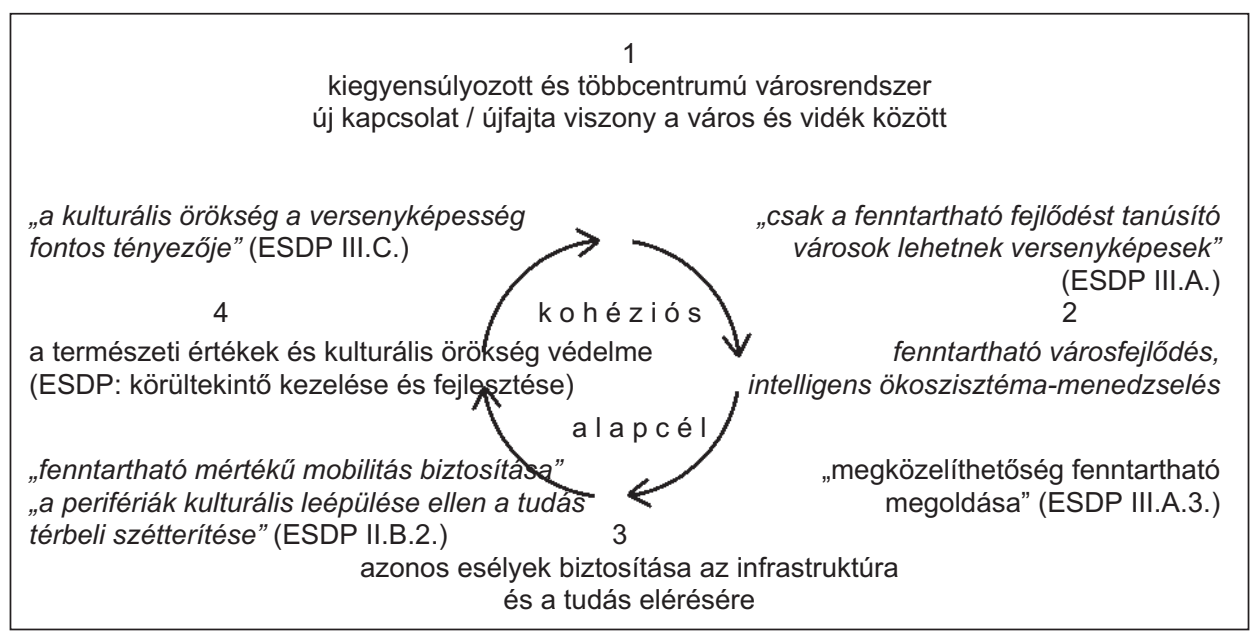

11. ábra

E célok a területpolitikai alapcéloknál lényegesen szembetűnőbb módon utópikusak (Vidor, 1994:149-150). Amíg a társadalmi-gazdasági kohézió szükségességének politikai alapcélként deklarálása nyomán nem kérhető számon a kohéziómegvalósítás tempója és mértéke, a területi tervezési célként megjelenő esélybiztositási egyenlöség konkrét vonatkozásokra szükítve (infrastruktúra és tudás) számonkérhető, és a leghatékonyabb aktivitás mellett is elégtelennek fog bizonyulni. Mintha a helyes politikai cél és a megvalósítás sajnálatos gyengeségének kettőse egykori tervgazdaságaink politikai trükkjei közül származott volna át. A célok csekély mértékü közelítését nem eredeztethetjük csupán a célképzés és célérvényesítés belső logikájából, hiszen a megvalósítás szükös forrásai és más külső-belső feltételek is lényeges szerepet játszanak.

A következtetési formák szerepét számottevönek kell tartanunk akkor, ha a töredékes megvalósulás nyilvánvalóvá válása után az irreális célok kitüzése továbbra is úgy marad meghatározó jellemzöje a területpolitikai dokumentumoknak, hogy a 
cél-együttes nem rendezödik át, nem szakad darabokra, és a nem-teljesülés nem ébreszt olyan mértékü konfliktust, mint az elkülönülten megjelenitett célok elérésére vonatkozó igéretek nem teljesitése.

A politikai alapcélok érvényesülésének folyamatábrái, illetve a jövőben a térés településstruktúra-fejlesztési célokra megfogalmazható hasonló kifejtések nem leendő folyamatok találó képei, és nem rendszer-meghatározások. Egy elemzési folyamat kísérleti modelljei. E kísérleti megközelítés továbbgondolása - a következtetési jellemzőknek jelentőséget tulajdonítva - a területpolitikai és területtervezési gyakorlat számára lényeges összefüggések feltárását, illetve meghatározásuk megerősítését segítheti elő.

Kiinduló feltevésem szerint a területi folyamatok alakulására ható uniós területpolitikákban sajátos racionalitás érvényesül, amely összefüggésbe hozható a következtetési formák szerveződésével. A célok realizálódásának mértékét a területpolitikai célok kapcsolatrendszerében kibontakozó korlátozó hatások körvonalazzák. A regionális politikák realitásoktól történő elrugaszkodásának mértékre fogására az eltérő következtetési formák lehetőséget adnak.

A társadalmi formációk, területi folyamatok, a politikai és tervezői fejlesztő beavatkozások következtetési szerkezetbe foglalása a területfejlesztéssel foglalkozó politikusok, tervezők rendszerépítő, modellező munkájában lényeges szerepet kaphat. Lehetőséget ad a duális, ellentétpárokra konstruált és az áttekinthetőség, az általánosítások szintje, a kapcsolódások szorossága tekintetében bizonytalan, többelemű rendszerezéseknél koherensebb és hierarchikusan továbbépíthető rendszerek, modellek kialakítására.

A politikák körében az ágazati politikákkal duális viszonyba foglalt területpolitikák egy a következtetési formák által kinált tágabb, indirekt visszacsatolásokkal müködö viszonyrendszerben jelenhetnek meg. A területi tervezés a közvetett kölcsönhatások árnyaltabb tekintetbevételére alkalmas modellezés irányába mozdulhat el.

A következtetési sémák a társadalmak nem-duális funkcionális rendszer-modelljeinek újrakonstruálására lehetőséget adnak. Az elméleti háttér, az értelmezési keretek, viszonyítási rendszerek következtetési formákba foglalásával a meghatározatlan vonásokat rendszerszerüen beszámító következtetési-folyamat modellek formálódhatnak ki. Az eltérő megközelítési módokból eredően eltérő következtetési fázisokban felerősödő, eltérő határozatlansági mozzanatok - a véletlen, valószínú, bizonytalan karakterek - az egyes következtetési formák specifikumaként jelenhetnek meg.

Ha a következtetési formákra érzékeny megközelítés alkalmazási köre a területi tervezés tárgykörén túl is érvényesíthető, a területi tervezés - a hozzá szorosan kapcsolódó urbanisztikai tervezéssel - mint kreatív impulzusok forrása jelenhet meg. 


\section{FÜGGELÉK}

A területpolitikai célkompozíciók körében bemutatott következtetési láncformák érvényesülése nyilvánvalóan nem korlátozódik e tárgykörre. Jelenlétüket más tudományterületeken példázza a tudásszociológia wittgensteini „erős programja” a vélekedések következtetéslogikai vonatkozásban igényes megközelítésével:

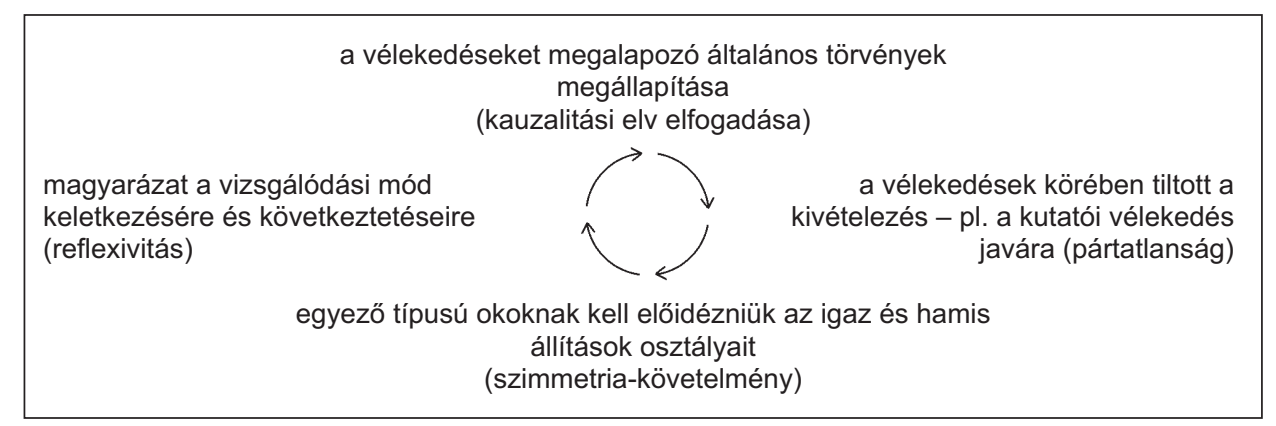

A területpolitikai célegyüttesek formálása során is érvényesülő, eltérő következtetési utakon eltérő jövőszemlélet érvényesül:

- deduktív úton a jövőkép bizonyos kétségtelenül érvényesnek vélt törvényszerüségek alapján, mintegy az ősbizalom jegyében, múlt-jelen képletek alapján extrapolált arculatú

- induktív megközelítéssel a jövőkép-megfogalmazás túláltalánosításra hajló, a jelenségek csupán néhány vonásuk kapcsán kerülnek kapcsolatba, erős az esély jelentéktelen és kivételes jegyek túlértékelésére

- az abduktív arculatú következtetés a múlt-jelen típusos formációinak módosulására esélyt ad; a variánsok, alváltozatok létrehozói, illetve az eltérések fokát kisebbítő sablonok, típusok erősítői preferáltak

- az eltérő viszonyítási rendszerek jelentőségét emeli ki az autoduktív megközelítés, teret engedve a még név nélküli jövő-lehetőségeknek, kitüntett figyelemmel az érték-pólusok közötti átmeneti zónák iránt.

A következtetési folyamatok mentén a meghatározási lehetőségek nyelvi adottságaink határáig érvényesülhetnek. Azonban e határokon belül, éppen a következtetési formához kötötten, további sajátos meghatározási korlátok érvényesülnek. $\mathrm{E}$ korlátok legkevésbé érzékelhetők deduktív logikai úton, ahol azokat a kiinduló tétel(ek) világossága elfedi. Induktív következtetési úton a véletlenek, abduktív úton a valószínüségi jellemzők, autoduktív következtetési forma mentén az előbbiektől karakteresen eltérő bizonytalan jellegek kívánnak figyelmet, gondos kifejtést. 


\section{IRODALOMJEGYZÉK}

Allan, P. - Schmidt, Ch. (1994): Game Theory and International Relations. Edward Elger, Aldershot.

Almond, Gabriel - A. Verba, Sidney (1969): A politikai kultúra vizsgálatához. Tud. Szoc. Füz. Bp. $65-72$.

Baráth Etele (1982): A rendszerszemléletü területi modell. Kézirat, VÁTI, Bp.

Bardach, Eugen (1977): The Implementation Game. The MIT Press, Cambridge, MA.

Barta Györgyi (1992): Fordulóponton a magyar területfejlesztési politika. Tér ésTársadalom, 1-2. $17-36$.

Bartke István (1996): A települések és a fenntartható fejlődés. Magyar Tudomány, 9. 1045-1056.

Brunda Gusztáv (1994): Szövetkezés. Kézirat, Salgótarján.

Bundesministerium für Raumordnung Bauwesen und Städtebau (1993): Raumordnungspolitischer Orientierungsrahmen. Bonn.

Castells, Manuel (1996): A Network Society - The net and the self economy, society and culture in the information age. Blackwell, Oxford.

CEC (1995): Environment in the European Union. CEC, Brussel.

CEC (1997): Towards Sustainability. CEC, Brussel.

CEMAT (1994): 10. ülés. Elfogadott Határozatok, Oslo, szept. 6-7.

CEMAT (1998): Rurális Térségek Európai Chartája. Ljubjana.

Checkland, Peter (1987): A rendszerelmélet elmélete és gyakorlata. Statisztikai Kiadó, Bp.

Downs, A. (1990): Politikai cselekvés a demokráciában (a racionális tájékozatlanság). Közgazdasági Szemle, 9. 991-1011.

ENSZ Környezet és Fejlesztés Világbizottság (1987): A K. és F.V. Jelentése (,Brundtlandjelentés”). Közös Jövőnk. Kézirat. VÁTI, Bp.

Erdősi Ferenc (1998): A transzeurópai hálózatok hatása a területi fejlődésre. Tér és Társadalom, 3. $27-51$.

E.S.D.P. (European Spatial Development Perspective) 1997. Noordwijk. Ford. Falu-Város-Régió, 1-3. sz. Megjelent: CEC: Cooperation across the European Territory. European Development Perspective: Summary of the First Official Draft. Inforegio.

EUREK (Europäisches Raumentwicklungskonzept). Auf dem Wege zu einer räumlich ausgewogenen und nachhaltigen Entwicklung der EU. 1999. május, Potsdam. Elérhető: www.Inforegio.cec.eu.int./wbdoc...: European Spatial Development Perspective (ESDP) (Potsdam, May 1999).

EUROPE 2000: Outlook for the development of the community's territory. (Európa 2000. A közösség jövőbeli területrendezésének perspektívái). 1991. CEC, Brussel-Hága-Luxemburg.

Eurostat (1998): Facts through Figures: A Statistical Portrait of the European Union. Brussels-Luxemburg.

Gombár Csaba (1992): Mi a politika. Osiris, Bp.

Gyulavári Tamás (szerk.) (2000): Az Európai Unió szociális dimenziója. Szociális és Családügyi Minisztérium, Bp.

Habermas, Jürgen (é. n.): A kommunikatív cselekvés elmélete. Fil. és Szoc. Figyelö, ELTE.

Horváth Gyula (1998a): Európai regionális politika. Dialóg Campus, Bp.-Pécs.

Horváth Gyula (1998b): Az európai regionális fejlődés és politikai távlatai. Tér és Társadalom, 3. $1-27$.

Hörcher Ferencné (1999): Szakmai tapasztalatok a PHARE Partnership-program kapcsán. Falu-Város-Régió, 4. 8-12. 
Hradil, Stefan (1987): Sozialstrukturanalyse in einer fortgeschrittenen Gesellschaft. Lesce+Budrich, Opladen.

Jenei György (1997): Közpolitikai döntések és a modern bürokrácia szerepének változása. Vezetéstudomány, 7-8. 4-5.

Korompai A. (1995): Regionális stratégiák jövőkutatási megalapozása. BKE, Bp. 95-97.

Kopátsy Sándor (2000): Mire építhetünk? In: Növekedés és globalizáció. Szerk.: Matolcsi György. Kairosz, Bp.

Kőszeghy Attila (1994): Fogalmak és jelentések a területi politika hatókörében. Tér és Társadalom, 3-4. 70-77.

Kunczmann, Peter - Burkhard, Peter - Wiedmann, Franz (1991): DTV-Atlas zur Philosophie. Deutscher Taschenbuch Verlag GmnH, München.

Meggyesi Tamás (1997): Az utópia és a „kenyőcs”. Urbanisztika, 8. 2 -4.

Miklóssy Endre (1996): A készülő területfejlesztési törvény. Vezetéstudomány, 1. 5-8.

Nemzetközi Természetvédelmi Unió, az ENSZ Környezetvédelmi Programja és a Természetvédelmi Világalap (1991): Földünkért. Az élet fenntartásának stratégiája. Gland, Svájc. Ford.: 1992, KTM, Bp.

Nemes-Nagy József (1998): A tér a társadalomkutatásban. Budapest.

Nijkamp, Peter - Reggiani, Aura (1992): Interaction, Evolution and Chaos in Space. Springer, Berlin.

Nováky Erzsébet (1994): Elörejelzés kaotikus viszonyok között. Vezetéstudomány, 7. sz. 60-62.

Nováky Erzsébet (1995): Káosz és jövökutatás. BKE, Bp.

Parsons, Talcott (1971): The System of Modern Societies. Cliffs, Englewood.

Peirce, Charles Sanders (1987): Textes fondamentaux de semiologie. Klincksieck, Paris.

Platz, H. - Samland, U. (1993): Raumordnerische Zielvorstellungen in europäischen Ländern. Informationen zur Raumentwicklung, 9-10. 585-591. (Deutsches Institut für Urbanistik Berlin)

Rechnitzer János (1998): Területi stratégiák. Dialógus Campus, Bp. - Pécs.

Searle, J. R. (1983): Intentionality. An essay in the philosophy of mind. Cambridge Univ. Press, Cambridge.

Segesváry Victor (1998a): Információ és tudás. Valóság, 12. 7-18.

Segesváry Victor (1998b): Globalizáció és világgazdaság. Valóság, 4. 1-22.

Szécsi Gábor (1998): Tudat, nyelv, kommunikáció. Áron, Bp.

Vidor Ferenc (1994): Az épitészeten innen és túl. Gyorsjelentés, Bp. 140-151.

Wallace, Walter (1971): The Logic of Science in Sociology. Aldine, Chicago.

Weber, Max (1992): Politik als Beruf. Max Weber Gesamtausgabe. Bd. I/17. Mohr, Tübingen. - Magyarul: A politika mint hivatás. Ford. Glavina Zs. 1995. Kossuth, Bp.

\section{REGIONAL POLITICAL AIM-COMPOSITIONS OF THE EUROPEAN UNION}

\section{Summary}

The European Spatial Development Perspective (1997) and in its more elaborated version, the European Spatial Development Conception (1999) surveys the consequences of the spatial development measures taken in the last decades and drafs the spatial development aims of the first decade of the next millennium. The basic political aims of the EU are integrated into a group of goals of equalization, social-economic cohesion and sustainability. 
Following the political manifestations in the Union - the aims of the regional policies of the nineties compared to the declared aims - one can notice that the results are moderate. Peculiar political rationality makes its way in the course of drafting the political aims. The acceptable successfulness of the regional policies are based on the moderately unrealistic forms of the aims. The rational construction of regional policies is realized - among others - through the joint success of the peculiar deduction forms. Along the different deduction ways different kinds of the definition limits of the different aim-approaches come into operation.

Keywords: regional policies, deduction, politics of European Union 
